\title{
A READILY AVAILABLE CHIRAL Ag-BASED NHC COMPLEX FOR USE IN EFFICIENT AND HIGHLY ENANTIOSELECTIVE RU-CATALYZED OLEFIN METATHESIS AND Cu-CATALYZED ALLYLIC ALKYLATION REACTIONS
}

\author{
Joshua J. Van Veldhuizen, John E. Campbell, Russell E. Giudici, and Amir H. Hoveyda* \\ Department of Chemistry, Merkert Chemistry Center, Boston College \\ Chestnut Hill, Massachusetts 02467
}

\section{Supporting Information}

General. Infrared (IR) spectra are recorded on a Nicolet 210 spectrophotometer, $v_{\max }$ in $\mathrm{cm}^{-1}$. Bands are characterized as broad (br), strong (s), medium (m), and weak (w). ${ }^{1} \mathrm{H}$ NMR spectra are recorded on a Varian Unity INOVA $400(400 \mathrm{MHz})$. Chemical shifts are reported in ppm from tetramethylsilane with the solvent resonance as the internal standard $\left(\mathrm{CDCl}_{3}: \delta 7.26\right)$. Data are reported as follows: chemical shift, multiplicity $(\mathrm{s}=$ singlet, $\mathrm{d}=$ doublet, $\mathrm{t}=$ triplet, $\mathrm{q}=$ quartet, sept $=$ septet, br $=$ broad, $\mathrm{m}=$ multiplet, ap = apparent $)$, coupling constants $(\mathrm{Hz})$, integration, and assignment. ${ }^{13} \mathrm{C}$ NMR spectra are recorded on a Varian Unity INOVA 400 (100 $\mathrm{MHz}$ ) with complete proton decoupling. Chemical shifts are reported in ppm from tetramethylsilane with the solvent resonance as the internal standard $\left(\mathrm{CDCl}_{3}: \delta 77.0\right)$. Enantiomer ratios are determined by chiral GLC or HPLC analysis [Alltech Associates Chiraldex GTA GLC column (30 m x $0.25 \mathrm{~mm}$ ), Supelco betadex 120 GLC column (30 m x $0.25 \mathrm{~mm}$ ), Supelco alphadex 120 GLC column (30 m x $0.25 \mathrm{~mm}$ ), Chiral Technologies Chiralcel OD, OJ, or Chiralpak AD, AS HPLC columns] in comparison with authentic racemic materials. Elemental analyses are performed by Robertson Microlit Laboratories (Madison, New Jersey). Highresolution mass spectra are recorded at the University of Illinois (Urbana-Champaign, IL) and on a Micromass LCT ESI-MS (positive mode) at the Mass Spectrometry Facility, Boston College. Optical rotation values are recorded on a Rudolph Research Analytical Autopol IV polarimeter.

All reactions are conducted in oven- $\left(135^{\circ} \mathrm{C}\right)$ and/or flame-dried glassware under an inert atmosphere of dry nitrogen. Solvents are purified under positive pressure of dry argon by a modified Advanced Chem Tech purification system. Benzene and toluene are purified through $\mathrm{Cu}$ and alumina columns, while dichloromethane is purified through two alumina columns. THF is purified by distillation over sodium/benzophenone-ketyl. Diethylzinc is purchased from Strem Chemicals Inc. or Aldrich Chemical Co. Dimethylzinc is purchased from Strem Chemicals Inc.; both are used as received. ${ }^{1}$ Diisopropylzinc (1M toluene) is purchased from Aldrich and di- $n$ butylzinc ( $1 \mathrm{M}$ heptane) is purchased from Lancaster. Enantiopure ( $>95 \%$ ee) (-)-S,Sdiphenylethylene diamine (DPEDA) is prepared following protocols outlined by Corey et al. ${ }^{2}$ $\mathrm{Ag}_{2} \mathrm{O}$ is prepared from the dropwise addition of $1 \mathrm{M}$ aqueous solution of $\mathrm{NaOH}$ to a $6 \mathrm{M}$ aqueous

\footnotetext{
${ }^{1}$ Knochel, P; Singer, R. Chem. Rev. 1993, 93, 2117-2188 and references cited therein.

2 (a) Corey, E. J.; Kühnle, N. M. Tetrahedron Lett. 1997, 38, 8631-8634. (b) Pikul. S.; Corey, E. J. Org. Synth. 1993, 71, 22-29.
} 
solution of $\mathrm{Ag}_{2} \mathrm{NO}_{3}$, collection of the resulting dark brown $\mathrm{Ag}_{2} \mathrm{O}$ precipitate, and drying the solid for $12 \mathrm{~h}$ in a vacuum dessicator with $\mathrm{P}_{2} \mathrm{O}_{5}$ prior to use. $\mathrm{CuCl}_{2} \cdot 2 \mathrm{H}_{2} \mathrm{O}$ is purchased from Aldrich and used without purification. Silia-P flash silica gel $\left(\mathrm{SiO}_{2}\right)$ purchased from Silicycle, $\mathrm{pH}(10 \%$ suspension) 6.5-7.0, is used in all chromatographic separations except for purification of ruthenium complexes (9-11) where Silica 60 silica gel purchased from TCI, 230-400 mesh, pH (10\% suspension) 6.5-7.0, is employed. All starting materials are synthesized from commercially available materials by well-established procedures. All allylic phosphates possess E-olefin geometry unless otherwise noted in the text; isomeric purity is established by ${ }^{1} \mathrm{H}$ NMR analysis (400 MHz).

Diamine (6). $\mathrm{Pd}(\mathrm{OAc})_{2}(4.0 \mathrm{mg}, 18 \mu \mathrm{mol}),( \pm)$-BINAP (22 mg, $\left.35 \mu \mathrm{mol}\right),(-)-(S, S)-1,2-$ diphenylethylenediamine (38.0 mg, $179 \mu \mathrm{mol})$, 2-methoxy-2'-iodo-1,1'-biphenyl (60.0 mg, 193 $\mu \mathrm{mol})$, and $\mathrm{NaO} t$-Bu $(34.4 \mathrm{mg}, 179 \mu \mathrm{mol})$ are placed into a vial in a glovebox. Toluene $(600 \mu \mathrm{L}$ is added and the vial sealed with a teflon-lined cap. The mixture is allowed to stir for $28 \mathrm{~h}$ at 90 ${ }^{\circ} \mathrm{C}$, at which time $\mathrm{NaOt}$-Bu $(34.4 \mathrm{mg}, 179 \mu \mathrm{mol})$, mesityl bromide $(27.4 \mu \mathrm{L}, 179 \mu \mathrm{mol})$ and toluene $(400 \mu \mathrm{L})$ are added and the mixture is allowed to stir for $30 \mathrm{~h}$. The reaction vessel is removed from the glovebox and the reaction is quenched by the addition of water $(1 \mathrm{~mL})$. The aqueous layer is washed with $\mathrm{CH}_{2} \mathrm{Cl}_{2}(3 \mathrm{x} 1 \mathrm{~mL})$. The organic layers are combined, dried over $\mathrm{MgSO}_{4}$, filtered and the solvent is removed in vacuo. Purification by silica gel chromatography (9:1 hexanes: $\mathrm{Et}_{2} \mathrm{O}, \mathrm{R}_{\mathrm{f}}=0.2$ ) gives 6 as a white solid $(69.8 \mathrm{mg}, 136 \mu \mathrm{mol}, 76 \%)$. mp: $182-183{ }^{\circ} \mathrm{C}$. IR (neat): 3402 (w), 3345 (w), 3062 (w), 3024 (w), 2999 (w), 2943 (w), 2911 (w), 2861 (w), 2842 (w), 1596 (m), 1577 (m), 1509 (s), 1484 (s), 1452 (s), 1316 (w), 1298 (w), 1269 (m), 1244 (m), 1230 (m), 1179 (w), 1160 (w), 1119 (w), 1051 (w), 1027 (m), 1004 (m), 885 (w), $854(\mathrm{w})$, 751 (s), 736 (s), 700 (s). NMR Spectrum exists as a mixture of 1:1 atropisomers. ${ }^{1} \mathbf{H}$ NMR (400 $\mathrm{MHz}_{\mathrm{CDCl}}$ ): $\delta$ 7.40-7.24 (m, 4.5H, $\left.\mathrm{ArH}\right), 7.17-7.04(\mathrm{~m}, 8.5 \mathrm{H}, \operatorname{ArH}), 6.95-6.88(\mathrm{~m}, 2 \mathrm{H}, \operatorname{ArH})$, 6.78-6.72 (m, 2H, ArH), $6.61(\mathrm{~d}, J=5.6 \mathrm{~Hz}, 2 \mathrm{H}, \operatorname{ArH}) 6.48(\mathrm{~d}, J=8.2 \mathrm{~Hz}, 0.5 \mathrm{H}, \operatorname{ArH}), 6.41$ (d, $J=8.1 \mathrm{~Hz}, 0.5 \mathrm{H}, \operatorname{ArH}), 5.81(\mathrm{~s}, 0.5 \mathrm{H}, \mathrm{NH}), 5.03(\mathrm{~d}, J=5.7 \mathrm{~Hz}, 0.5 \mathrm{H}, \mathrm{NH}$ or NCH), 4.89 (dd, $J$ $=6.1,6.1 \mathrm{~Hz}, 0.5 \mathrm{H}, \mathrm{NH}$ or $\mathrm{NCH}), 4.80(\mathrm{dd}, J=8.5,1.8 \mathrm{~Hz}, 0.5 \mathrm{H}, \mathrm{NH}$ or NCH), 4.35 (br s, $0.5 \mathrm{H}, \mathrm{NH}$ or $\mathrm{NCH}), 4.18(\mathrm{dd}, J=9.5,9.5 \mathrm{~Hz}, 0.5 \mathrm{H}, \mathrm{NH}$ or $\mathrm{NCH}), 3.68\left(\mathrm{~s}, 1.5 \mathrm{H}, \mathrm{OCH}_{3}\right), 3.67$ (s, 1.5H, $\left.\mathrm{OCH}_{3}\right), 3.46-3.38(\mathrm{~m}, 1 \mathrm{H}, \mathrm{NH}$ or $\mathrm{NCH}), 2.14\left(\mathrm{~s}, 1.5 \mathrm{H}, \mathrm{ArCH}_{3}\right), 2.13\left(\mathrm{~s}, 1.5, \mathrm{ArCH}_{3}\right), 1.85$ $\left(\mathrm{s}, 6 \mathrm{H}, \mathrm{ArCH}_{3}\right) .{ }^{13} \mathrm{C}$ NMR $\left(100 \mathrm{MHz}, \mathrm{CDCl}_{3}\right): \delta 157.0,156.9,145.4,144.7,141.5,141.3,140.9$, $140.8,140.6,140.5,132.2,132.0,130.8,130.7,130.5,130.5,129.7,129.7,129.0,129.0,128.9$, $128.6,128.5,128.4,128.3,128.1,128.1,128.1,128.0,128.0,127.7,127.4,127.3,127.0,126.2$, $125.9,121.3,121.2,117.2,117.0,112.1,111.7,111.1,110.9,67.4,66.5,62.7,61.7,55.5,55.3$, 20.6, 20.5, 19.1, 18.9. HRMS Calcd for $\mathrm{C}_{36} \mathrm{H}_{37} \mathrm{~N}_{2} \mathrm{O}\left(\mathrm{M}+\mathrm{H}^{+}\right)$: 513.2906. Found: 513.2902. Anal. Calcd for $\mathrm{C}_{36} \mathrm{H}_{36} \mathrm{~N}_{2} \mathrm{O}$ : C, 84.34; H, 7.08; N, 5.46. Found: C, 84.26; H, 7.04; N, 5.44.

Diamine alcohol (Intermediate from 6 to 7). To a solution of methyl ether 6 (497 mg, 0.970 $\mathrm{mmol})$ in dry $\mathrm{CH}_{2} \mathrm{Cl}_{2}(10 \mathrm{~mL})$ is added $\mathrm{BBr}_{3}(550 \mu \mathrm{L}, 5.82 \mathrm{mmol})$ over five minutes at $0{ }^{\circ} \mathrm{C}$. The mixture is allowed to warm to $22{ }^{\circ} \mathrm{C}$ and allowed to stir for $6 \mathrm{~h}$. A saturated solution of aqueous 
$\mathrm{NaHCO}_{3}(30 \mathrm{~mL})$ is slowly added at $0{ }^{\circ} \mathrm{C}$, the mixture is allowed to stir for $30 \mathrm{~min}$ at which time the aqueous layer is washed with $\mathrm{CH}_{2} \mathrm{Cl}_{2}(3 \times 20 \mathrm{~mL})$. The organic layers are combined, dried over $\mathrm{MgSO}_{4}$, filtered and the solvent is removed in vacuo. Purification by silica gel chromatography $\left(9: 1\right.$ hexanes: $\left.\mathrm{Et}_{2} \mathrm{O}, \mathrm{R}_{\mathrm{f}}=0.2\right)$ affords a white solid (434 $\left.\mathrm{mg}, 0.869 \mathrm{mmol}, 90 \%\right)$. IR (neat): 3526 (w), 3343 (w), 3245 (w), 3061 (m), 3029 (m), 3004 (m), 2919 (m), 2855 (m), 2735 (w), 1701 (w), 1632 (m), 1599 (m), 1578 (m), 1480 (s), 1451 (s), 1376 (w), 1342 (w), 1310 (m), 1290 (m), 1273 (m), 1228 (m), 1194 (m), 1154 (m), 1027 (w), 1001 (w), 909 (w), 854 (m), 828 (w), 754 (s), 701 (s), 730 (s). Both ${ }^{1} \mathrm{H}$ and ${ }^{13} \mathrm{C}$ NMR spectrum exhibit mostly broad peaks. ${ }^{1} \mathbf{H}$ NMR $\left(400 \mathrm{MHz}, \mathrm{CDCl}_{3}\right.$ ): $\delta$ 7.38-6.76 (m, 13H, ArH and OH), $7.00(\mathrm{ddd}, J=7.4,7.4,1.1$ Hz, 2H, ArH) 6.93-6.76 (m, 4H, ArH), 6.60 (s, 2H, ArH), 6.11 (br s, 1H, NH), 4.77 (br s, 1H, $\mathrm{NCH}$ ), 4.28 (br s, 1H, NCH), 3.28 (br s, 1H, NH), 2.11 (s, 3H, $\operatorname{ArCH}_{3}$ ), 1.89 (s, 6H, $\left.\operatorname{ArCH}{ }_{3}\right) .{ }^{13} \mathbf{C}$ NMR $\left(100 \mathrm{MHz}, \mathrm{CDCl}_{3}\right): \delta 153.9,144.2,140.4,140.0,131.9,131.6,131.4,129.8,129.7,129.6$, 129.3, 129.1, 129.1, 129.0, 128.6, 128.2, 128.0, 127.8, 127.6, 127.6, 126.8, 126.7, 121.4, 120.0, 117.8, 113.7, 67.5, 63.2, 20.5, 19.0. HRMS Calcd for $\mathrm{C}_{35} \mathrm{H}_{35} \mathrm{~N}_{2} \mathrm{O}\left(\mathrm{M}+\mathrm{H}^{+}\right)$: 499.2749. Found: 499.2729.

Imidazolinium chloride (7). Anhydrous hydrogen chloride is gently introduced into a solution of diamine alcohol $(1.62 \mathrm{~g}, 3.25 \mathrm{mmol})$ in methanol $(32 \mathrm{~mL})$ for $5 \mathrm{~min}$ at $-78{ }^{\circ} \mathrm{C}$, resulting in a tan colored precipitate. The mixture is allowed to warm to $22{ }^{\circ} \mathrm{C}$ and the solvent is removed in vacuo. The white solid is dried in a dessicator over $\mathrm{P}_{2} \mathrm{O}_{5}$ under vacuum. Triethylorthoformate (30 $\mathrm{mL}$ ) is added and the round bottom is equipped with a short path distillation head. The mixture is allowed to stir at $125^{\circ} \mathrm{C}$ for $4 \mathrm{~h}$ with occasional heating of the distillation head with a heat gun to facillitate ethanol removal. The vessel is cooled to $22{ }^{\circ} \mathrm{C}$ and $\mathrm{Et}_{2} \mathrm{O}(30 \mathrm{~mL})$ is added dropwise to form a precipitate that is filtered and washed with $\mathrm{Et}_{2} \mathrm{O}(2 \times 10 \mathrm{ml})$ to yield 7 as a white solid (883 mg, $1.62 \mathrm{mmol}, 50 \%) .{ }^{1} \mathbf{H}$ NMR (400 MHz, $\mathrm{CDCl}_{3}$ ): $\delta 10.48$ (s, 1H, OH), 8.91 (s, 1H, NCHN), 7.79 (d, J=8.2 Hz, 1H, ArH), 7.69 (s, 1H, ArH), 7.42 (dd, J=6.9, 6.9 Hz, 2H, ArH), 7.33-7.00 (m, 12H, ArH), $6.79(\mathrm{~s}, 1 \mathrm{H}, \operatorname{ArH}), 6.71(\mathrm{~d}, J=7.5 \mathrm{~Hz}, 2 \mathrm{H}, \operatorname{ArH}), 6.47(\mathrm{~s}, 1 \mathrm{H}, \operatorname{ArH})$, $5.36(\mathrm{~d}, J=9.8 \mathrm{~Hz}, 1 \mathrm{H}, \mathrm{NCH}), 5.28(\mathrm{~d}, J=9.8 \mathrm{~Hz}, 1 \mathrm{H}, \mathrm{NCH}), 2.56\left(\mathrm{~s}, 3 \mathrm{H}, \mathrm{CH}_{3}\right), 2.11(\mathrm{~s}, 3 \mathrm{H}$, $\left.\mathrm{CH}_{3}\right), 1.81\left(\mathrm{~s}, 3 \mathrm{H}, \mathrm{CH}_{3}\right) .{ }^{13} \mathbf{C}$ NMR $\left(100 \mathrm{MHz}, \mathrm{CDCl}_{3}\right): \delta 157.7,155.3,139.8,137.6,136.0$, 135.2, 134.1, 133.1, 132.4, 132.3, 130.5, 130.4, 130.3, 130.0, 129.9, 129.8, 129.6, 129.1, 128.9, 128.8, 128.7, 127.9, 125.2, 119.9, 118.5, 75.5, 72.3, 21.0, 19.5, 18.8. HRMS Calcd for

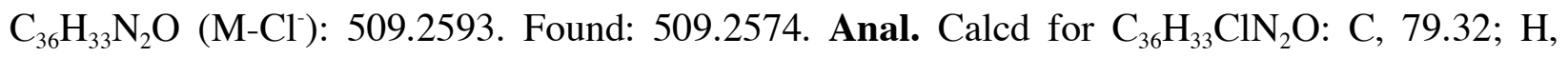
$6.10 ; \mathrm{N}, 5.14$. Found: C, 79.25; H, 6.00; N, 5.08.

Silver(I) complex (8). To a mixture of imidazolinium chloride 7 (58.4 mg, $0.107 \mathrm{mmol}), \mathrm{Ag}_{2} \mathrm{O}$ (51 mg, $0.22 \mathrm{mmol}$ ), and $4 \AA$ mol sieves (bead, $100 \mathrm{mg}$ ) in $10 \mathrm{~mL}$ round bottom flask equipped with a reflux condenser is added THF $(0.75 \mathrm{~mL})$ and benzene $(0.75 \mathrm{~mL})$. The mixture is allowed to stir at reflux for $3 \mathrm{~h}$ at which time the vessel is cooled to $22{ }^{\circ} \mathrm{C}$ and the mixture filtered through a Celite plug $(1 / 5 \mathrm{~cm}, \mathrm{w} / \mathrm{l})$. The Celite is washed with $\mathrm{CH}_{2} \mathrm{Cl}_{2}$ and the combined solvent is removed in vacuo to give an off-white solid complex 8 (64.1 $\mathrm{mg}, 0.052 \mathrm{mmol}$, 97\%). This 
material is obtained in crystalline form by recrysallization from $\mathrm{CH}_{2} \mathrm{Cl}_{2}: \mathrm{Et}_{2} \mathrm{O}$, but recrystallization is not required for effective transmetallation and further catalysis. mp: 195-197 ${ }^{\circ} \mathrm{C}$ (decomp). IR (neat): 3032 (m), 3007 (m), 2919 (m), 2861 (w), 1600 (w), 1582 (m), 1548 (w), 1489 (s), 1465 (s), 1451 (s), 1436 (s), 1376 (w), 1345 (w), 1301 (s), 1275 (s), 1217 (m), 1199 (m), $1147(\mathrm{w}), 1115(\mathrm{w}), 1077(\mathrm{w}), 1034(\mathrm{w}), 1003(\mathrm{~m}), 899(\mathrm{w}), 850(\mathrm{~m}), 757$ (s), $735(\mathrm{~s}), 700$ (s). ${ }^{1} \mathbf{H}$ NMR (400 MHz, $\mathrm{CDCl}_{3}$ ): $\delta$ 7.40-7.32 (m, 5H, ArH), 7.26-7.13 (m, 5H, ArH), 7.07 (d, $J$ $=7.14 \mathrm{~Hz}, \operatorname{ArH}), 7.02-6.96(\mathrm{~m}, 3 \mathrm{H}, \operatorname{ArH}), 6.89$ (dd, J = 7.7, 7.6 Hz, 1H, ArH), 6.71-6.61 (m, $3 \mathrm{H}, \operatorname{ArH}), 6.56(\mathrm{dd}, J=7.2,7.1 \mathrm{~Hz}, 1 \mathrm{H}, \operatorname{ArH}), 5.40(\mathrm{~d}, J=10.5 \mathrm{~Hz}, 1 \mathrm{H}, \mathrm{NCH}), 5.36(\mathrm{~d}, J=8.1$ $\mathrm{Hz}, 1 \mathrm{H}, \operatorname{ArH}), 5.16$ (d, J = $10.5 \mathrm{~Hz}, 1 \mathrm{H}, \mathrm{NCH}), 2.53$ (s, 3H, CH $\left.\mathbf{H}_{3}\right), 2.36$ (s, 3H, CH $), 1.23$ (s, $\left.3 \mathrm{H}, \mathrm{CH}_{3}\right) .{ }^{13} \mathrm{C} \mathbf{N M R}\left(100 \mathrm{MHz}, \mathrm{CDCl}_{3}\right): \delta 234.0\left(J_{\mathrm{C}^{109} \mathrm{Ag}}=268.4 \mathrm{~Hz}, J_{\mathrm{C}^{107} \mathrm{Ag}}=232.7 \mathrm{~Hz}\right), 167.8$, $143.1,138.7,138.2$, 138.1, 137.5, 135.7, 135.5, 135.2, 132.7, 129.5, 129.5, 129.3, 129.2, 129.1, $129.0,128.8,128.7,128.7,128.6,128.4,128.2,126.4,122.1,111.3,78.1,78.0,76.4,76.3,21.2$, 19.1, 18.9. $[\alpha]_{\mathrm{D}}{ }^{25}\left(c=0.993, \mathrm{CHCl}_{3}\right):-71.8^{\circ}$.

Ruthenium complex (9). To biphenyl tosyl hydrazone ${ }^{3}$ (400 mg, $0.980 \mathrm{mmol}$ ), in a $50 \mathrm{~mL}$ round bottom is added tetramethyl guanidine $(10.0 \mathrm{~mL}, 94.6 \mathrm{mmol})$ and water $(0.05 \mathrm{~mL}, 2.8$ mmol). The resulting solution is allowed to stir for $30 \mathrm{~min}$ at $23{ }^{\circ} \mathrm{C}$ or until the solid has completely dissolved. After stirring for $20 \mathrm{~min}$ at $55^{\circ} \mathrm{C}$, the solution changes color from yellow to red. Cold water $(10 \mathrm{~mL})$ is added and the aqueous layer is washed with $n$-pentane $(3 \mathrm{x} 20 \mathrm{~mL})$. The combined organic layers are washed with saturated aqueous $\mathrm{NaHCO}_{3}(3 \times 20 \mathrm{~mL})$ followed by brine $(3 \times 20 \mathrm{~mL})$. The combined organics are dried with $\mathrm{Na}_{2} \mathrm{SO}_{4}$, filtered and the solvent is removed in vacuo to afford a red colored oil. The oil is redissolved in $n$-pentane and cooled to $78{ }^{\circ} \mathrm{C}$, whereupon the mixture is transferred by cannula into a solution of dichlorotristriphenylphosphine ruthenium $(600 \mathrm{mg}, 0.630 \mathrm{mmol})$, in $\mathrm{CH}_{2} \mathrm{Cl}_{2}(10 \mathrm{~mL})$ at $-78{ }^{\circ} \mathrm{C}$. The reaction is allowed to stir for $10 \mathrm{~min}$, then warmed to $22{ }^{\circ} \mathrm{C}$ and the solvent is purged away by a slow stream of $\mathrm{N}_{2}$. Excess $\mathrm{AgCl}(500 \mathrm{mg}, 3.48 \mathrm{mmol})$ is added to a solution of the dark brown/red solid dissolved in minimal $\mathrm{CH}_{2} \mathrm{Cl}_{2}(2 \mathrm{~mL})$. After $5 \mathrm{~min}$ the solution is added directly to a column of TCI silica gel and purified by silica gel chromatography $\left(2: 1 \mathrm{CH}_{2} \mathrm{Cl}_{2}\right.$ :hexanes) yielding 9 as a dark brown solid (320 mg, $0.486 \mathrm{mmol}, 77 \%$ ). The oxygen and moisture sensitive product is stored under $\mathrm{N}_{2}$ at $0{ }^{\circ} \mathrm{C}$ prior to use. ${ }^{1} \mathbf{H} \mathbf{N M R}\left(400 \mathrm{MHz}, \mathrm{CDCl}_{3}\right): \delta 16.81(\mathrm{~d}, J=6.8$ $\mathrm{Hz}, 1 \mathrm{H}, \mathrm{RuCH})$, 7.60-7.54 (m, $12 \mathrm{H}, \mathrm{ArH}), 7.50-7.38$ (m, 8H, ArH), 7.31 (dd, J = 7.6, 15.2 Hz, $3 \mathrm{H}, \operatorname{ArH}), 7.16$ (t, $J=7.2 \mathrm{~Hz}, 1 \mathrm{H}, \mathrm{ArH}), 4.88$ (ddddd, $J=2.8,6.0,9.6,12.8,15.6 \mathrm{~Hz}, 1 \mathrm{H}$, $\left.\operatorname{OCH}\left(\mathrm{CH}_{3}\right)_{2}\right), 1.44\left(\mathrm{~d}, J=6.4 \mathrm{~Hz}, 6 \mathrm{H}, \mathrm{CH}\left(\mathrm{CH}_{3}\right)_{2}\right) .{ }^{13} \mathbf{C ~ N M R}\left(100 \mathrm{MHz}, \mathrm{CDCl}_{3}\right) ; \delta$ 279.2, 212.0, 139.5, 134.2, 134.1, 133.8, 131.8, 131.2, 130.7, 129.0, 128.9, 128.7, 128.6, 128.5, 123.9, 31.7, 14.3. HRMS Calcd for $\mathrm{C}_{34} \mathrm{H}_{31} \mathrm{ClOPRu}\left(\mathrm{M}-\mathrm{Cl}^{-}\right)$: 623.0861. Found: 623.0826 .

Ruthenium(II) chloride complex (10). Please not that this Ru complex is oxygen and moisture sensitive and should be kept under nitrogen at all times and purified with distilled and degassed

\footnotetext{
${ }^{3}$ Kingsbury, J. S.; Harrity, J. P. A.; Bonitatebus, P. J., Jr; Hoveyda, A. H. J. Am. Chem. Soc. 1999, 121, $791-799$.
} 
solvents. A solution of $\mathbf{8}(55.6 \mathrm{mg}, 45.2 \mu \mathrm{mol})$ in THF $(1 \mathrm{~mL})$ and benzene $(1 \mathrm{~mL})$ is transferred by cannula into a flask containing $\mathrm{Ru}$ complex $9(65.5 \mathrm{mg}, 99.5 \mu \mathrm{mol})$ and equipped with a reflux condenser. The mixture is allowed to stir at reflux for $1 \mathrm{~h}$, allowed to cool to $22{ }^{\circ} \mathrm{C}$ and the solvent is removed in vacuo. The residue is dissolved in a minimal amount of $\mathrm{CH}_{2} \mathrm{Cl}_{2}(0.2 \mathrm{~mL})$ and this solution is transferred by cannula onto a column of silica gel (TCI, Silcia 60) that has been purged with nitrogen and $\mathrm{CH}_{2} \mathrm{Cl}_{2}$. The product is eluted with $\mathrm{CH}_{2} \mathrm{Cl}_{2}$ into a round bottom flask under nitrogen and the solvent is removed in vacuo to afford $\mathbf{1 0}$ as a brown residue. ${ }^{1} \mathbf{H}$ NMR (400 MHz, $\mathrm{CDCl}_{3}$ ): $\delta 16.01$ (s, 1H, RuCH), 7.61-6.93 (m, 24H, ArH), 6.86-6.84 (m, 2H, $\operatorname{ArH}), 6.50-6.45(\mathrm{~m}, 2 \mathrm{H}, \mathrm{ArH}), 5.11$ (d, $J=9.7 \mathrm{~Hz}, 1 \mathrm{H}, \mathrm{NCH}), 4.92$ (d, $J=9.7 \mathrm{~Hz}, 1 \mathrm{H}, \mathrm{NCH})$, $\left.4.34(\mathrm{qq}, J=6.2 \mathrm{~Hz}, 1 \mathrm{H}, \mathrm{OCH}), 2.55\left(\mathrm{~s}, 3 \mathrm{H}, \operatorname{ArCH}_{3}\right), 2.36\left(\mathrm{~s}, 3 \mathrm{H}, \operatorname{ArCH}_{3}\right), 1.43(\mathrm{~s}, 3 \mathrm{H}, \operatorname{ArCH})\right)$, $0.82\left(\mathrm{~d}, J=6.2 \mathrm{~Hz}, 3 \mathrm{H}, \mathrm{CHCH}_{3}\right), 0.74\left(\mathrm{~d}, J=6.1 \mathrm{~Hz}, 3 \mathrm{H}, \mathrm{CHCH}_{3}\right) .{ }^{13} \mathbf{C} \mathbf{~ N M R}(100 \mathrm{MHz}$, $\left.\mathrm{CDCl}_{3}\right): \delta 283.5,215.7,171.3,149.4,147.3,142.9,139.8,139.4,138.7,138.3,138.0,136.9$, $136.5,136.3$, 134.6, 131.6, 131.6, 131.5, 131.0, 130.4, 129.9, 129.3, 129.2, 129.1, 129.0, 129.0, $128.8,128.7,129.0,128.6,128.4,128.2,127.7,127.6,123.8,123.1,120.9,117.2,78.1$, 77.6, 76.0, 21.1, 20.1, 19.8, 19.5, 19.0 .

Ruthenium(II) iodide complex (11). To the brown residue 10 is added sodium iodide (136 mg, $907 \mu \mathrm{mol})$ and THF ( $1 \mathrm{~mL})$. The mixture is allowed to stir at reflux for $1 \mathrm{~h}$ after which the solvent is removed in vacuo and the resulting oil is purified by silica gel chromatography (TCI Silica 60) (1:1 hexanes: $\left.\mathrm{CH}_{2} \mathrm{Cl}_{2}\right)$ to afford 11 as a brown residue (43.8 $\left.\mathrm{mg}, 45.6 \mu \mathrm{mol}, 50 \%\right)$. IR (neat): 3426 (s), 2923 (s), 2853 (s), 1665 (w), 1634 (m), 1607 (w), 1462 (m), 1377 (w), 792 (w), 699 (w). ${ }^{1} \mathbf{H}$ NMR (400 MHz, $\mathrm{CDCl}_{3}$ ): $\delta 15.61$ (s, 1H, RuCH), 7.72-7.70 (m, 1H, ArH), 7.487.44 (m, 4H, ArH), 7.39-7.16 (m, 16H, ArH), 7.05 (ddd, J=7.2, 7.2, 0.9 Hz, 3H, ArH), 6.96$6.91(\mathrm{~m}, 2 \mathrm{H}, \operatorname{ArH}), 6.84(\mathrm{dd}, J=7.6,1.7 \mathrm{~Hz}, 1 \mathrm{H}, \operatorname{ArH}), 6.79(\mathrm{~s}, 1 \mathrm{H}, \operatorname{ArH}), 5.13(\mathrm{~d}, J=9.3 \mathrm{~Hz}$, 1H, NCH), 4.93 (d, $J=9.4 \mathrm{~Hz}, 1 \mathrm{H}, \mathrm{NCH}), 4.40$ (qq, $J=6.3,6.3 \mathrm{~Hz}, 1 \mathrm{H}, \mathrm{OCH}), 2.63$ (s, 3H, $\left.\operatorname{ArCH}_{3}\right), 2.33$ (s, 3H, ArCH$), 1.48\left(\mathrm{~s}, 3 \mathrm{H}, \operatorname{ArCH}_{3}\right), 0.84\left(\mathrm{~d}, J=6.3 \mathrm{~Hz}, 3 \mathrm{H}, \mathrm{CH}\left(\mathrm{CH}_{3}\right)_{3}\right), 0.73$ (d, $\left.J=6.3 \mathrm{~Hz}, 3 \mathrm{H}, \mathrm{CH}\left(\mathrm{CH}_{3}\right)_{3}\right) .{ }^{13} \mathbf{C} \mathbf{~ N M R}\left(100 \mathrm{MHz} \mathrm{CDCl}_{3}\right): \delta 283.3,215.9,170.1,149.7,147.6$, $143.1,139.8,139.6,139.3,138.4,137.6,137.0,136.5,136.3,135.1,131.9,131.7,131.6,131.0$, $130.5,129.9,129.5,129.2,129.1,129.1,129.0,128.8,128.7,128.7,128.5,128.2,127.7,127.5$, $123.9,123.5,120.9,117.2,78.0,78.0,76.1,34.8,25.4,21.2,21.1,20.7,20.3,19.4$. HRMS Calcd for $\mathrm{C}_{52} \mathrm{H}_{48} \mathrm{~N}_{2} \mathrm{O}_{2} \mathrm{IRu}\left(\mathrm{M}+\mathrm{H}^{+}\right)$: 961.1804. Found: 961.1797.

Note on compound characterization. All new compounds are reported with full characterization below. A number of compounds synthesized in this study have been prepared and fully characterized previously. ${ }^{4,5}$ When relevant, reference to the Supporting Information of these papers should be made. For compound 13, see ref. 4.

\footnotetext{
${ }^{4}$ Van Veldhuizen, J. J.; Garber, S. B.; Kingsbury, J. S.; Hoveyda, A. H. J. Am. Chem. Soc. 2002, 124, 4954-4955.

${ }^{5}$ Gillingham, D. G.; Kataoka, O.; Garber, S. B.; Hoveyda, A. H. J. Am. Chem. Soc. 2004, 125, 12288-12290.
} 
Pyran-4-ol (15). (See ref. 5) Bicycle 14 (6.8 mg, $54 \mu \mathrm{mol})$ is dissolved in THF (540 $\mu \mathrm{L})$ and the resulting solution is added to a solution of Ru complex $11(2.6 \mathrm{mg}, 2.7 \mu \mathrm{mol})$ dissolved in styrene $(12.4 \mu \mathrm{L}, 108 \mu \mathrm{mol})$ by a syringe pump within $1-1.5 \mathrm{~h}$. The resulting mixture is allowed to stir at $22{ }^{\circ} \mathrm{C}$ for $1 \mathrm{~h}$. Silica gel $(100 \mathrm{mg})$ is added and the solvent is removed in vacuo. The product-laden silica gel is loaded onto a column of silica gel and the product is eluted (4:1 hexanes: $\left.\mathrm{Et}_{2} \mathrm{O}, \mathrm{R}_{\mathrm{f}}=0.21\right)$. This procedure affords $\mathbf{1 5}$ as a white solid $(8.7 \mathrm{mg}, 38 \mu \mathrm{mol}, 70 \%)$. Once the product has eluted off the column, the catalyst is recovered by further elution $(1: 1$ hexanes: $\mathrm{CH}_{2} \mathrm{Cl}_{2}$ ) to give recovered $\mathbf{1 1}$ as a brown residue $(1.1 \mathrm{mg}, 1.1 \mu \mathrm{mol}, 42 \%)$.

Pyran-4-one (17). To a mixture of bicycle 16 (7.0 mg, $56 \mu \mathrm{mol})$ and Ru complex 11 (2.7 mg, $2.8 \mu \mathrm{mol})$ is added styrene $(33 \mu \mathrm{L}, 0.29 \mathrm{mmol})$. The mixture is allowed to stir at $22{ }^{\circ} \mathrm{C}$ for $1.5 \mathrm{~h}$. Silica gel $(100 \mathrm{mg})$ is added and the solvent is removed in vacuo. The product-laden silica gel is loaded onto a column of silica gel and the product is eluted (10:1 hexanes: $\mathrm{Et}_{2} \mathrm{O}, \mathrm{R}_{\mathrm{f}}=0.18$ ). This procedure delivers 17 as a white solid $(9.4 \mathrm{mg}, 41 \mu \mathrm{mol}, 74 \%)$. IR (neat): 3081 (w), 3059 (w), $3026(\mathrm{w}), 2968$ (w), 2902 (w), 2850 (w), 1720 (s), 1496 (w), 1411 (m), 1332 (m), $1247(\mathrm{~m})$, 1055 (m), 967 (m), 931 (m), 748 (m), 693 (m). ${ }^{1} \mathbf{H}$ NMR (400 MHz, CDCl $)$ : $\delta$ 7.41-7.35 (m, 2H, $\operatorname{ArH}), 7.35-7.21(\mathrm{~m}, 3 \mathrm{H}, \mathrm{ArH}), 6.65(\mathrm{~d}, J=15.9 \mathrm{~Hz}, 1 \mathrm{H}, \mathrm{PhCH}), 6.25(\mathrm{dd}, J=16.1,6.0 \mathrm{~Hz}, 1 \mathrm{H}$, PhCHCH), 5.96 (ddd, $\left.J=17.2,10.6,5.7 \mathrm{~Hz}, 1 \mathrm{H}, \mathrm{CH}=\mathrm{CH}_{2}\right), 5.35(\mathrm{ddd}, J=17.2,1.3,1.3 \mathrm{~Hz}, 1 \mathrm{H}$, $\left.\mathrm{CH}=\mathrm{CH}_{2}\right), 5.23\left(\mathrm{ddd}, J=10.6,1.3,1.3 \mathrm{~Hz}, 1 \mathrm{H}, \mathrm{CH}=\mathrm{CH}_{2}\right), 4.34(\mathrm{dddd}, J=10.1,6.0,4.6,1.1 \mathrm{~Hz}$, $1 \mathrm{H}, \mathrm{OCH}), 4.26-4.18(\mathrm{~m}, 1 \mathrm{H}, \mathrm{OCH}), 2.57-2.37\left(\mathrm{~m}, 4 \mathrm{H},\left(\mathrm{CH}_{2}\right)_{2} \mathrm{CO}\right) .{ }^{13} \mathbf{C}$ NMR $(100 \mathrm{MHz}$, $\left.\mathrm{CDCl}_{3}\right): \delta 205.9,137.0,136.2,131.7,128.7,128.1,128.1,126.7,116.6,77.5,77.4,47.8,47.4$. HRMS Calcd for $\mathrm{C}_{15} \mathrm{H}_{16} \mathrm{O}_{2}: 228.1150$. Found: 228.1151 . $[\alpha]_{\mathrm{D}}{ }^{25}\left(c=0.199, \mathrm{CHCl}_{3}\right):-42.0^{\circ}$.

Pyran (19). A solution of norbornene $\mathbf{1 8}(10.6 \mathrm{mg}, 70.8 \mu \mathrm{mol})$ in THF $(700 \mu \mathrm{L})$ is added over 1 h by syringe pump to a solution of Ru complex $11(3.4 \mathrm{mg}, 3.5 \mu \mathrm{mol})$ in styrene $(40.5 \mu \mathrm{L}, 354$ $\mu \mathrm{mol})$. The resulting mixture is allowed at $22{ }^{\circ} \mathrm{C}$ to stir for $1 \mathrm{~h}$. Silica gel $(150 \mathrm{mg})$ is added and the solvent is removed in vacuo. The product-laden silica gel is loaded onto a column of silica gel and the product is eluted $\left(50: 1\right.$ hexanes: $\left.\mathrm{Et}_{2} \mathrm{O}, \mathrm{R}_{\mathrm{f}}=0.21\right)$. This procedure affords 19 as a white solid $(8.30 \mathrm{mg}, 184 \mu \mathrm{mol}, 52 \%)$. Once the product has eluted off the column the catalyst is recovered by further elution $\left(1: 1\right.$ hexanes: $\left.\mathrm{CH}_{2} \mathrm{Cl}_{2}\right)$ to give recovered $\mathbf{1 1}$ as a brown residue (1.5 $\mathrm{mg}, 1.6 \mu \mathrm{mol}, 45 \%) .{ }^{1} \mathbf{H} \mathbf{N M R}\left(400 \mathrm{MHz}, \mathrm{CDCl}_{3}\right): \delta 7.36(\mathrm{~d}, J=7.7 \mathrm{~Hz}, 2 \mathrm{H}, \mathrm{ArH}), 7.28(\mathrm{dd}, J=$ 7.8, $7.8 \mathrm{~Hz}, 2 \mathrm{H}, \operatorname{ArH}), 7.18$ (dddd, $J=7.3,7.3,1.3,1.3 \mathrm{~Hz}, 1 \mathrm{H}, \operatorname{ArH}), 6.47(\mathrm{~d}, J=15.8 \mathrm{~Hz}, 1 \mathrm{H}$, $\mathrm{PhCH}$ ), 6.19 (dd, $J=15.8,8.0 \mathrm{~Hz}, 1 \mathrm{H}, \mathrm{PhCHCH}$ ), 5.96 (dddd, $J=10.1,2.1,2.1,2.1 \mathrm{~Hz}, 1 \mathrm{H}$, $\mathrm{C}=\mathrm{CH}), 5.62(\mathrm{dddd}, J=10.1,2.6,2.6,2.6 \mathrm{~Hz}, 1 \mathrm{H}, \mathrm{C}=\mathrm{CH}), 4.42-4.30\left(\mathrm{~m}, 2 \mathrm{H}, \mathrm{OCH}_{2}\right), 3.21(\mathrm{dd}, J$ $=10.0,10.0 \mathrm{~Hz}, 1 \mathrm{H}, \mathrm{OCH}), 2.65(\mathrm{dddd}, J=10.2,10.2,8.4,8.4 \mathrm{~Hz}, 1 \mathrm{H}, \mathrm{C}=\mathrm{CHCH}), 2.38-2.27$ $(\mathrm{m}, 1 \mathrm{H}, \mathrm{C}=\mathrm{CHCH}), 2.12\left(\mathrm{dddd}, J=13.6,9.9,9.9,7.6 \mathrm{~Hz}, 1 \mathrm{H}, \mathrm{CH}_{2} \mathrm{CH}_{2}\right), 1.86$ (dddd, $J=12.2$, 9.7, 7.6, $2.6 \mathrm{~Hz}, 1 \mathrm{H}, \mathrm{CH}_{2} \mathrm{CH}_{2}$ ), 1.62 (dddd, $J=13.6,10.7,8.0,2.6 \mathrm{~Hz}, 1 \mathrm{H}, \mathrm{CH}_{2} \mathrm{CH}_{2}$ ), 1.30 (dddd, $\left.J=12.6,12.6,11.0,7.6 \mathrm{~Hz}, 1 \mathrm{H}, \mathrm{CH}_{2} \mathrm{CH}_{2}\right) .{ }^{13} \mathbf{C} \mathbf{N M R}\left(100 \mathrm{MHz}, \mathrm{CDCl}_{3}\right): \delta 137.6,132.7,130.5$, 128.7, 128.5, 127.0, 126.4, 126.2, 84.9, 68.4, 45.2, 41.2, 27.8, 23.7. HRMS Calcd for $\mathrm{C}_{16} \mathrm{H}_{18} \mathrm{O}$ : 226.1358. Found: 226.1357. $[\alpha]_{\mathrm{D}}{ }^{25}\left(c=0.10, \mathrm{CHCl}_{3}\right):+6.7^{\circ}$. 


\section{Authentic Racemic Product}

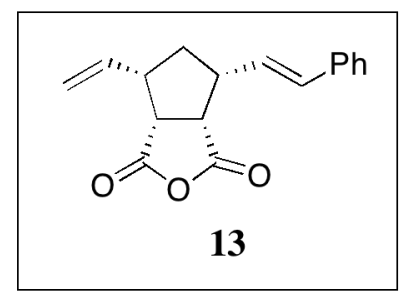

Furan-1,3-dione (13)

\section{Enantioenriched $(90 \%$ ee)}

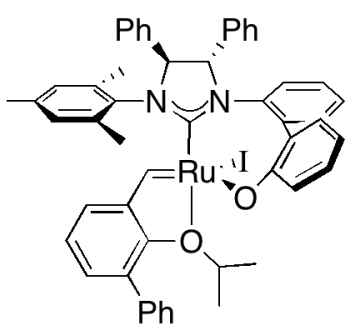

11

\section{Enantioenriched $(\mathbf{7 0} \%$ ee)}

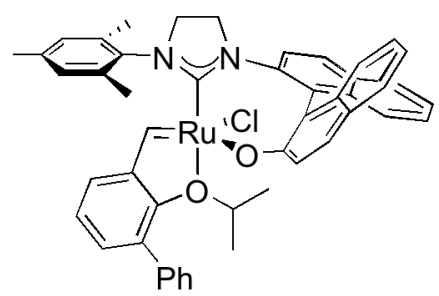

1b

Enantioenriched $(84 \%$ ee)

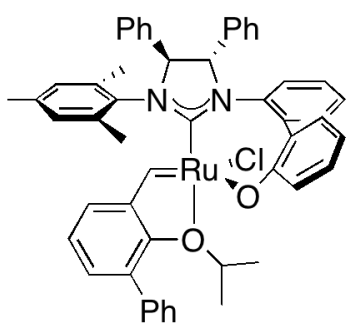

10

Chiral HPLC: 95:5 Hexanes: 2-propanol, $0.75 \mathrm{~mL} / \mathrm{min}$, Chiralcel AS, $240 \mathrm{~nm}$ 


\section{Authentic Racemic Product}

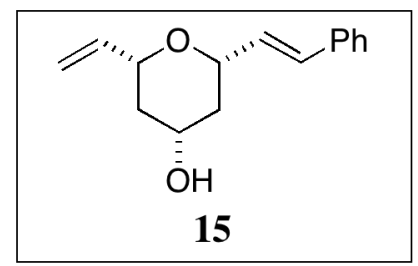

Pyran-4-ol (15)

\section{Enantioenriched (93\% ee)}

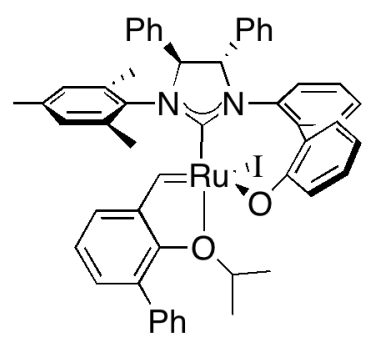

11

\section{Enantioenriched (94\% ee)}

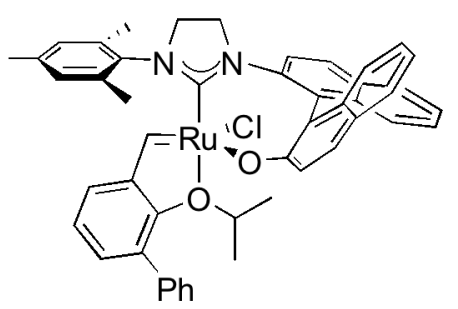

1b

\section{Enantioenriched (74\% ee)}

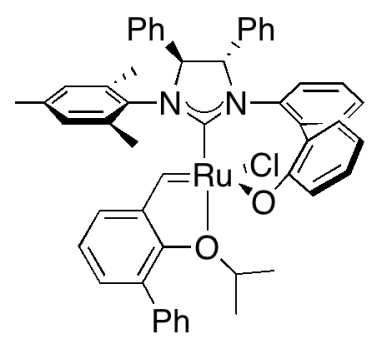

10

Chiral HPLC: 98:2 Hexanes: 2-propanol, $1.0 \mathrm{~mL} / \mathrm{min}$, Chiralcel AS, $254 \mathrm{~nm}$ 


\section{Authentic Racemic Product}

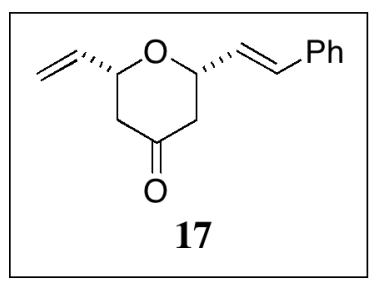

Pyran-4-one (17)

\section{Enantioenriched (84\% ee)}

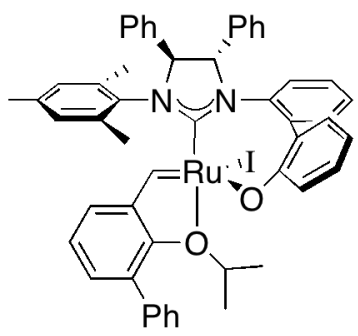

11

\section{Enantioenriched (67\% ee)}

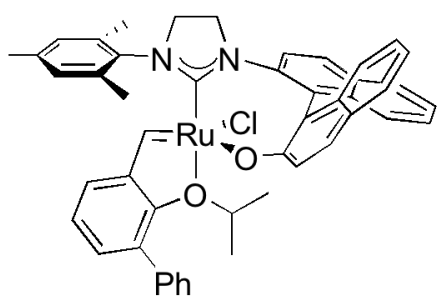

1b

Enantioenriched (71\% ee)

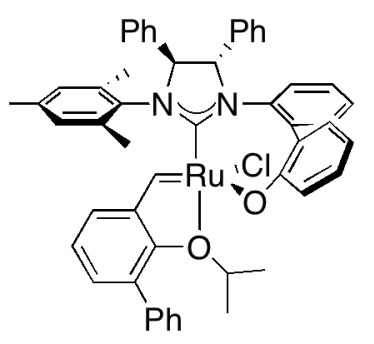

10

Chiral HPLC: 99:1 Hexanes: 2-propanol, $1.0 \mathrm{~mL} / \mathrm{min}$, Chiralcel AD, $254 \mathrm{~nm}$ 


\section{Authentic Racemic Product}

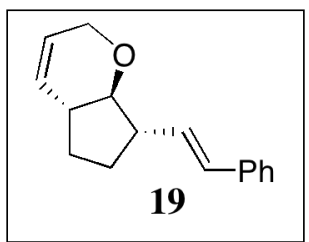

Pyran (19)

\section{Enantioenriched $(90 \%$ ee)}

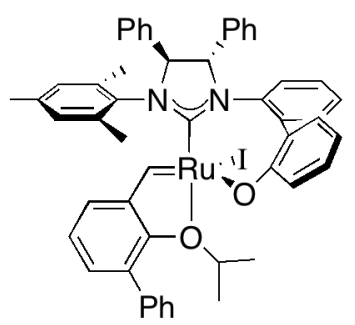

11

\section{Enantioenriched (46\% ee)}

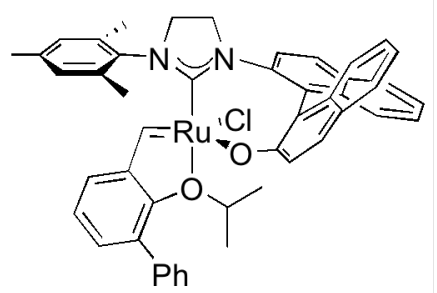

$1 b$

\section{Enantioenriched (84\% ee)}

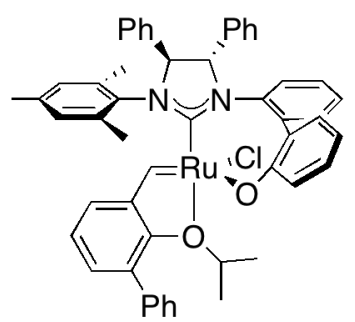

10

Chiral HPLC: 99.5:0.5 Hexanes: 2-propanol, $1.0 \mathrm{~mL} / \mathrm{min}$, Chiralcel OD, $254 \mathrm{~nm}$ 


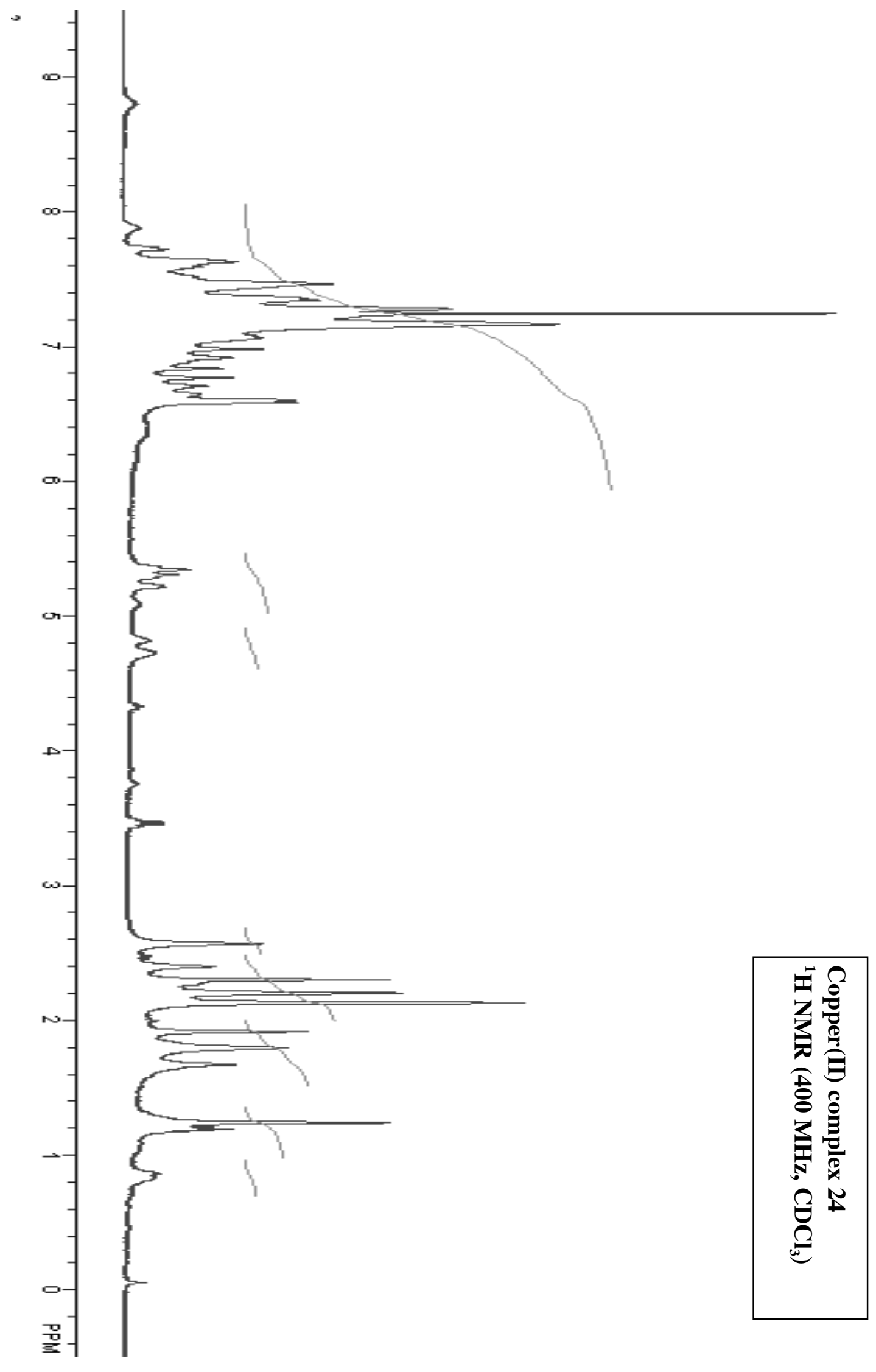


Copper(II) complex (24). To $\mathrm{Ag}(\mathrm{I})$ complex 8 (8.5 mg, $7.0 \mu \mathrm{mol})$ in $\mathrm{CH}_{2} \mathrm{Cl}_{2}(1 \mathrm{~mL})$ is added $\mathrm{CuCl}_{2} \cdot 2 \mathrm{H}_{2} \mathrm{O}$ as a $0.01 \mathrm{M}$ solution in THF $(1.40 \mathrm{~mL}, 14.0 \mu \mathrm{mol})$. The resulting mixture is allowed to stir at $22{ }^{\circ} \mathrm{C}$ until it becomes homogenous $(3 \mathrm{~h})$. The resulting mixture is passed through a plug of Celite $\left(1 / 5 \mathrm{~cm}\right.$, w/l) and washed with $\mathrm{CH}_{2} \mathrm{Cl}_{2}(3 \times 10 \mathrm{~mL})$ to remove silver precipitates. The solvent is removed in vacuo to afford the desired product $\mathbf{2 4}$ as a dark red microcrystalline solid that is used without further purification $(7.9 \mathrm{mg}, 6.7 \mu \mathrm{mol}, 95 \%)$. Alternatively, the material can be recrystallized from $\mathrm{CH}_{2} \mathrm{Cl}_{2}$ :pentane to afford dark red crystals. The results reported in this paper are achieved through the use of non-recrystallized samples. Data is provided below for the non-recrystallized compound. mp: $139-141{ }^{\circ} \mathrm{C}$. IR (neat): $3351(\mathrm{w})$, 2963 (m), 2933 (s), 2865 (m), 1731 (m), 1700 (m), 1630 (m), 1596 (m), 1490 (m), 1466 (m), 1447 (m), 1287 (m), 1109 (w), 1041 (w), 912 (m), 739 (s), 702 (m). ${ }^{1}$ H NMR (400 MHz, $\left.\mathrm{CDCl}_{3}\right)$ : broad signals, spectra given above (p. S11). $[\alpha]_{\mathbf{D}}{ }^{25}\left(c=0.223, \mathrm{CHCl}_{3}\right):-347.0^{\circ}$.

\section{Representative experimental procedures for the Cu-catalyzed allylic alkylation of dialkylzinc reagents to allylic phosphates}

Method A: An oven-dried 13 x $100 \mathrm{~mm}$ test tube is fitted with a septum, sealed with teflon tape and then placed under a nitrogen atmosphere. $\mathrm{CuCl}_{2} \cdot 2 \mathrm{H}_{2} \mathrm{O}(0.20 \mathrm{~mL}, 2.0 \mu \mathrm{mol})$ is added as a $0.01 \mathrm{M}$ solution in THF and the reaction vessel is cooled to $-78{ }^{\circ} \mathrm{C}$, after which dimer $\mathrm{Ag}(\mathrm{I})$ complex $8(1.23 \mathrm{mg}, 1.00 \mu \mathrm{mol})$ is added in one portion as a solution in THF $(0.4 \mathrm{~mL})$. After the solution is allowed to stir for $5 \mathrm{~min}, \mathrm{Et}_{2} \mathrm{Zn}(60 \mu \mathrm{L}, 0.60 \mathrm{mmol}, 3.0$ equiv.) (CAUTION: $\mathrm{Et}_{2} \mathrm{Zn}$ IS PYROPHORIC! USE EXTREME CAUTION!) is added dropwise, followed by the addition of (E)-3-phenyl-2-propen-1-ol phosphate $(56 \mathrm{mg}, 0.20 \mathrm{mmol})$ as a solution in THF $(0.4$ $\mathrm{mL}$ ). The light brown solution is placed in a cooling bath set to $-15{ }^{\circ} \mathrm{C}$ and reaction progress monitored by TLC analysis. Upon completion, indicated by a dark red colored solution, excess $\mathrm{Et}_{2} \mathrm{Zn}$ is quenched by the dropwise addition of distilled water $(0.1 \mathrm{~mL})$ and the organic layer is diluted with $\mathrm{Et}_{2} \mathrm{O}(5 \mathrm{~mL})$. The organic layer is filtered through silica gel with $\mathrm{Et}_{2} \mathrm{O}$ and the solvent is removed in vacuo. The resulting residue is purified by silica gel chromatography (100\% pentane) to yield $(S)-3$-phenyl-1-pentene as a colorless liquid (19.9 mg, $0.136 \mathrm{mmol}$, $68 \%)$.

Method B: An oven dried 13 x $100 \mathrm{~mm}$ test tube is charged with dimer $\mathrm{Cu}(\mathrm{II})$ complex $24(1.1 \mathrm{mg}, 0.90 \mu \mathrm{mol})$ on the benchtop, fitted with a septum, and sealed with teflon tape. The reaction vessel is placed under a nitrogen atmosphere and allowed to cool to $-78{ }^{\circ} \mathrm{C}$ where dry THF $(0.6 \mathrm{~mL})$ is added. $\mathrm{Et}_{2} \mathrm{Zn}\left(60 \mu \mathrm{L}, 0.60 \mathrm{mmol}, 3.0\right.$ equiv.) (CAUTION: $\mathrm{Et}_{2} \mathrm{Zn}$ IS PYROPHORIC! USE EXTREME CAUTION!) is added dropwise followed by the slow addition of $(E)$-3-(o-methoxyphenyl)-2-buten-1-ol phosphate $(63 \mathrm{mg}, 0.20 \mathrm{mmol})$ as a solution in THF $(0.4 \mathrm{~mL})$. The resulting light yellow solution is placed in a cooling bath set to $-15{ }^{\circ} \mathrm{C}$ and reaction progress monitored by TLC analysis. Upon completion of the reaction, (red color) excess $\mathrm{Et}_{2} \mathrm{Zn}$ is quenched by the dropwise addition of distilled water $(0.1 \mathrm{~mL})$ and the organic layer is diluted with $\mathrm{Et}_{2} \mathrm{O}(5 \mathrm{~mL})$. The organic layer is filtered through silica gel with $\mathrm{Et}_{2} \mathrm{O}$ and the solvent is removed in vacuo. The resulting residue is purified by silica gel chromatography 
(100\% pentane) to yield $(S)-3-(o$-methoxyphenyl)-3-methyl-1-pentene as a colorless oil (34.7 mg, $0.182 \mathrm{mmol}, 91 \%$ ).

Method C: For reactions in which the alkyl zinc reagent is available as a 1.0 M solution ( $i \mathrm{Pr}_{2} \mathrm{Zn}, 1.0 \mathrm{M}$ toluene, Aldrich, or $n \mathrm{Bu}_{2} \mathrm{Zn}, 1.0 \mathrm{M}$ heptane, Lancaster), the above procedures are followed with the exception of the quantity and composition of the reaction solvent employed. For example: An oven-dried 13 x $100 \mathrm{~mm}$ test tube is fitted with a septum, sealed with teflon tape and then placed under a nitrogen atmosphere. $\mathrm{CuCl}_{2} \cdot 2 \mathrm{H}_{2} \mathrm{O}(0.20 \mathrm{~mL}, 2.0 \mu \mathrm{mol})$ is added as a $0.01 \mathrm{M}$ solution in $\mathrm{THF}$ and the reaction vessel is cooled to $-78{ }^{\circ} \mathrm{C}$, after which $\operatorname{dimer} \operatorname{Ag}(\mathrm{I})$ complex $8(1.23 \mathrm{mg}, 1.00 \mu \mathrm{mol})$ is added in one portion as a solution in THF $(0.4 \mathrm{~mL})$. After the solution is allowed to stir for $5 \mathrm{~min}$, a $1.0 \mathrm{M}$ solution of $i \mathrm{Pr}_{2} \mathrm{Zn}$ in toluene $(0.60 \mathrm{~mL}, 0.60 \mathrm{mmol}$, 3.0 equiv.) (CAUTION: $i \operatorname{Pr}_{2} \mathrm{Zn}$ IS PYROPHORIC! USE EXTREME CAUTION!) is added dropwise, followed by the addition of $(E)$-3-phenyl-2-propen-1-ol phosphate (56 $\mathrm{mg}, 0.20 \mathrm{mmol}$ ) as a solution in THF $(0.2 \mathrm{~mL})$. The light brown solution is placed in a cooling bath set to $-15{ }^{\circ} \mathrm{C}$ and reaction progress monitored by TLC analysis. Upon completion, indicated by a dark red colored solution, excess $i \operatorname{Pr}_{2} \mathrm{Zn}$ is quenched by the dropwise addition of distilled water $(0.1 \mathrm{~mL})$ and the organic layer is diluted with $\mathrm{Et}_{2} \mathrm{O}(5 \mathrm{~mL})$. The organic layer is filtered through silica gel with $\mathrm{Et}_{2} \mathrm{O}$ and the solvent is removed in vacuo. The resulting residue is purified by silica gel chromatography (100\% pentane) to yield $(S)$-3-Phenyl-4-methyl-1-pentene as a colorless liquid (25.6 mg, $0.16 \mathrm{mmol}, 80 \%)$. It should be noted that the total volume in these reactions is $1.4 \mathrm{~mL}$ (relative to $1.0 \mathrm{~mL}$ in previous examples) and thus reaction times can be longer.

Note on separation of enantioenriched products by chiral GLC/HPLC. Derivitization of select asymmetric allylic alkylation products is necessary to achieve separation on available chiral chromatography columns. When required, the resulting vinyl group is treated with $\mathrm{O}_{3}$ in $\mathrm{CH}_{2} \mathrm{Cl}_{2}$ : $\mathrm{MeOH}$ (1:1) followed by addition of $\mathrm{NaBH}_{4}$ (3.0 equiv) to quench the ozonide and reduce the aldehyde directly to the terminal alcohol. Protection of the alcohol with $\mathrm{Ac}_{2} \mathrm{O}, \mathrm{NEt}_{3}$, DMAP affords the acetate in quantitative yield. This derivitization is required for $(\boldsymbol{S})$-3-phenyl1-heptene, $\quad(R)-3-p h e n y l-3-(p$-nitrophenyl)-1-pentene, $\quad(S)$-3-methyl-1-decene, $\quad(S)$-3cyclohexyl-1-butene, (S)-3-methyl-3-cyclohexyl-1-pentene, $(S)$-3-methyl-3-ethyl-7-methylocta-1,6-diene. The unprotected alcohol is used to separate $(\boldsymbol{S})$-3-ethyl-1-decene.

Note on compound characterization. All new compounds are reported with full characterization below. A number of compounds synthesized in this study have been prepared and fully characterized previously. ${ }^{6,7}$ When relevant, reference to the Supporting Information of these papers should be made.

\footnotetext{
${ }^{6}$ Kacprzynski, M. A.; Hoveyda, A. H. J. Am. Chem. Soc. 2004, 126, 10676-10681.

${ }^{7}$ Larsen, A. O.; Leu, W.; Oberhuber, C. N.; Campbell, J. E.; Hoveyda, A. H. J. Am. Chem. Soc. 2004, 126, $11130-$ 11131.
} 
(S)-3-Phenyl-1-heptene (Table 2, entry 3). (Method C) IR (neat): 3074 (w), 3043 (w), 2968 (m), 2936 (m), 2867 (m), 1740 (s), 1614 (m), 1457 (m), 1275 (br), 1111 (br), 1035 (m), 979 (w), $771(\mathrm{~m}), 721$ (s). ${ }^{1} \mathbf{H}$ NMR (400 MHz, $\mathrm{CDCl}_{3}$ ): $\delta$ 7.15-7.33 (m, 5H, ArH), 5.95 (ddd, $J=16.5$, 10.8, 7.5 Hz, 1H, C=CH), 4.99-5.05 (m, 2H, C=CH), 3.23 (ap q, $J=7.5 \mathrm{~Hz}, 1 \mathrm{H}, \mathrm{CH}), 1.65-1.76$ $\left(\mathrm{m}, 2 \mathrm{H}, \mathrm{CH}_{2}\right), 1.12-1.36\left(\mathrm{~m}, 4 \mathrm{H}, \mathrm{CH}_{2} \mathbf{C H}_{2}\right), 0.87$ (t, $\left.J=7.5 \mathrm{~Hz}, 3 \mathrm{H}, \mathrm{CH}_{3}\right) .{ }^{13} \mathbf{C ~ N M R}(100 \mathrm{MHz}$, $\left.\mathrm{CDCl}_{3}\right): \delta 144.9,142.8,128.6,127.8,126.3,114.0,50.1,35.4,30.0,22.9,14.2$. Anal. Calcd for $\mathrm{C}_{13} \mathrm{H}_{18}: \mathrm{C}, 89.59 ; \mathrm{H}, 10.41$; Found: $\mathrm{C}, 89.22 ; \mathrm{H}, 10.76 .[\alpha]_{\mathbf{D}}{ }^{25}\left(c=2.37, \mathrm{CHCl}_{3}\right):+6.62^{\circ}$ (Note: Optical rotation of the corresponding acetate pictured below).

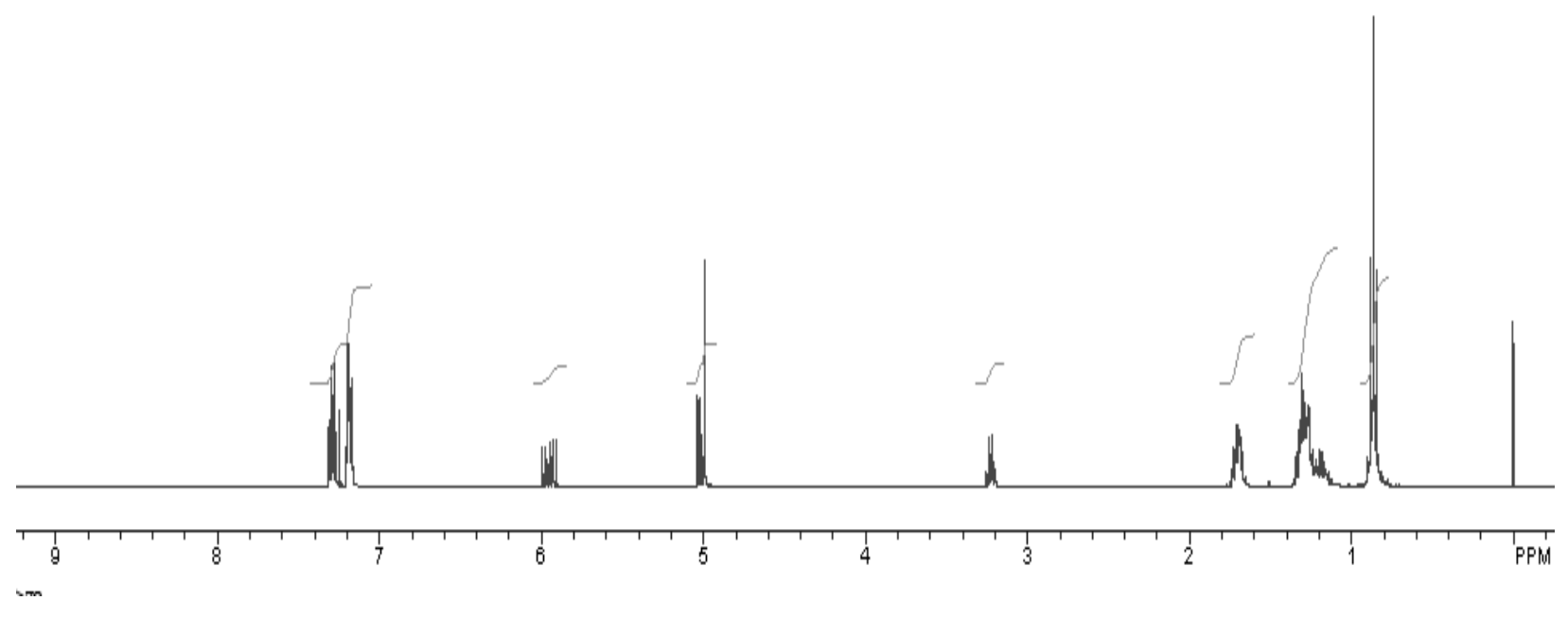

Enantioenriched Sample (89\% ee)

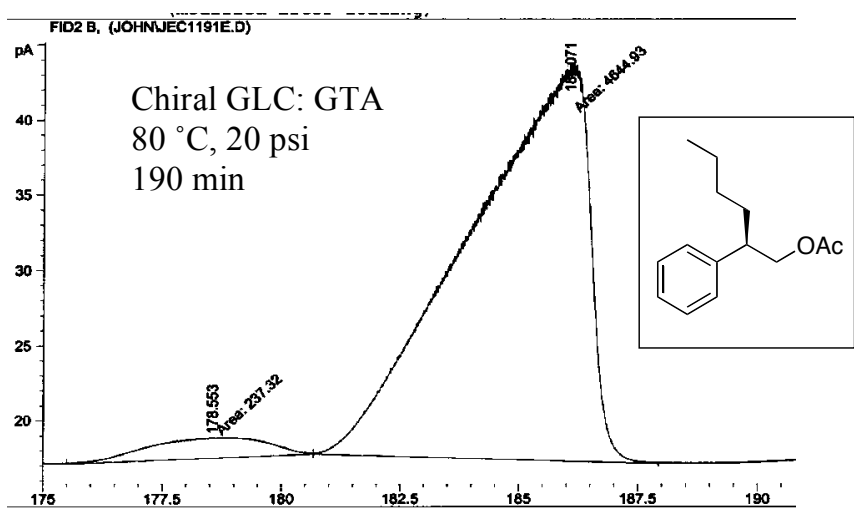

\section{Authentic Racemic Sample}

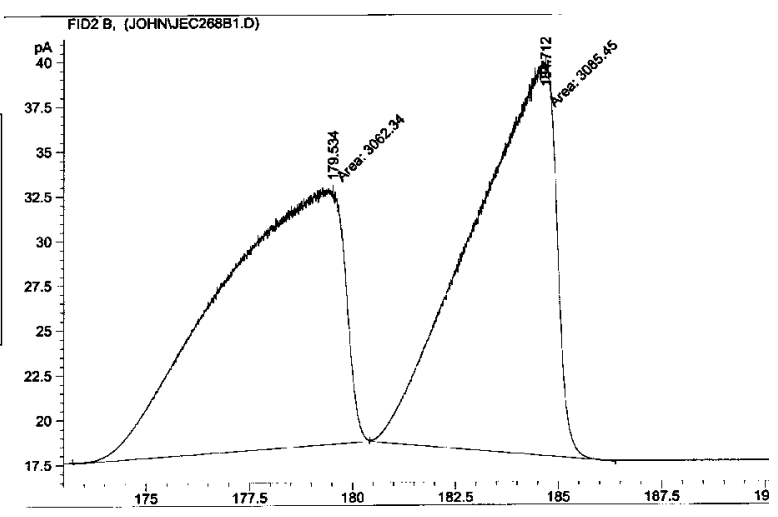


(S)-3-Phenyl-4-methyl-1-pentene (Table 2, entry 4). (Method C) IR (neat): 3080 (w), 3033 (w), 2963 (m), 2925 (m), 2872 (m), 1644 (w), 1493 (w), 1451 (w), 1386 (w), 920 (m), 759 (w). ${ }^{1} \mathbf{H}$ NMR $\left(400 \mathrm{MHz}, \mathrm{CDCl}_{3}\right): \delta$ 7.13-7.32 (m, 5H, ArH), $5.97(\mathrm{~m}, 1 \mathrm{H}, \mathrm{C}=\mathrm{CH}), 5.03(\mathrm{~m}, 1 \mathrm{H}$, $\mathrm{C}=\mathrm{CH}), 4.99(\mathrm{~m}, 1 \mathrm{H}, \mathrm{C}=\mathrm{CH}), 2.87($ ap t $, J=9.0 \mathrm{~Hz}, 1 \mathrm{H}, \operatorname{ArCH}), 1.94(\mathrm{dspt}, J=9.0,6.8 \mathrm{~Hz}, 1 \mathrm{H}$, $\left.\mathrm{CH}\left(\mathrm{CH}_{3}\right)_{2}\right), 0.95\left(\mathrm{~d}, J=6.8 \mathrm{~Hz}, 3 \mathrm{H}, \mathrm{CH}_{3}\right), 0.75\left(\mathrm{~d}, J=6.8 \mathrm{~Hz}, 3 \mathrm{H}, \mathrm{CH}_{3}\right) .{ }^{13} \mathbf{C} \mathbf{~ N M R}(100 \mathrm{MHz}$, $\left.\mathrm{CDCl}_{3}\right): \delta 144.5,141.4,128.5,128.1,126.2,115.1,58.7,32.8,21.2,21.0$. Anal. Calcd for $\mathrm{C}_{12} \mathrm{H}_{16}$ : C, 89.94; H, 10.06; Found: C, 89.73; H, 10.28. [ $\left.\alpha\right]_{\mathrm{D}}{ }^{25}\left(c=0.720, \mathrm{CHCl}_{3}\right):+1.11^{\circ}$.

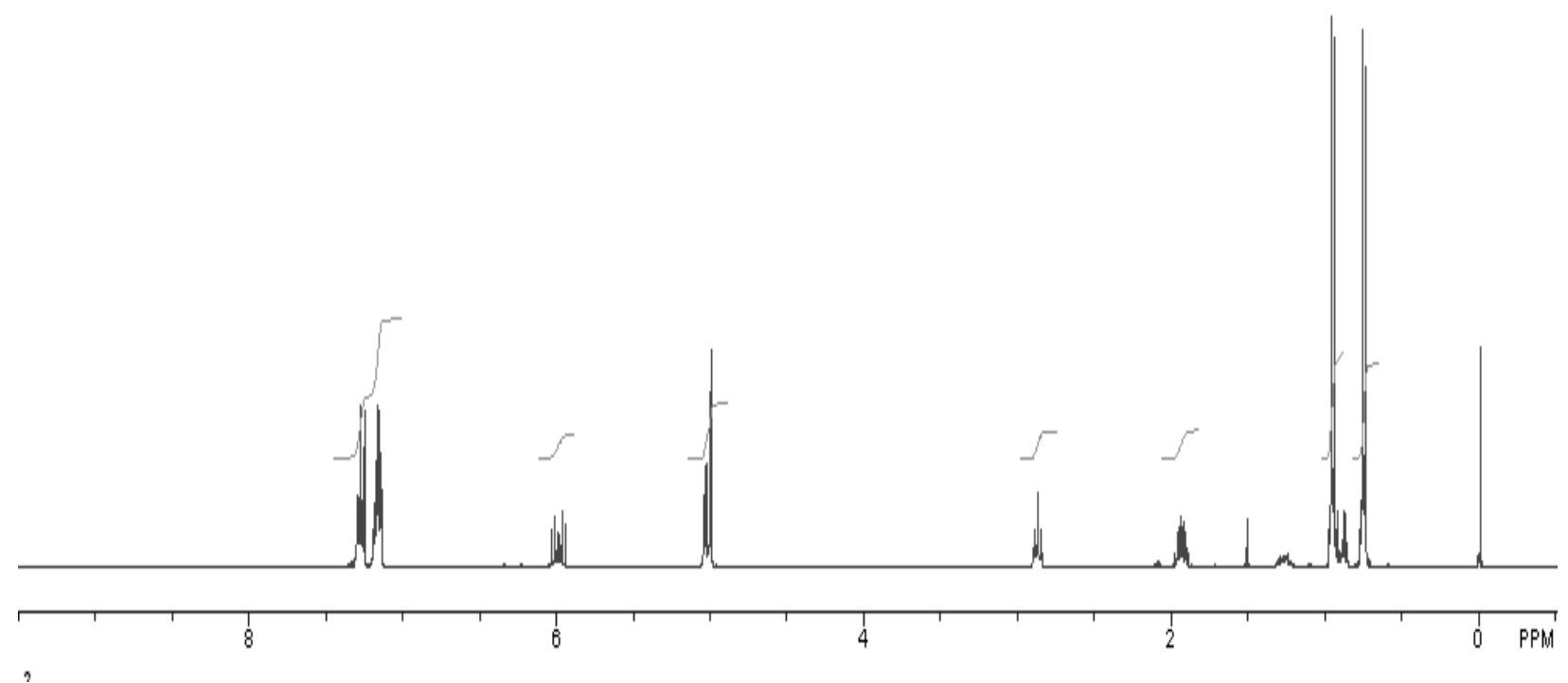

Enantioenriched Sample (86\% ee)

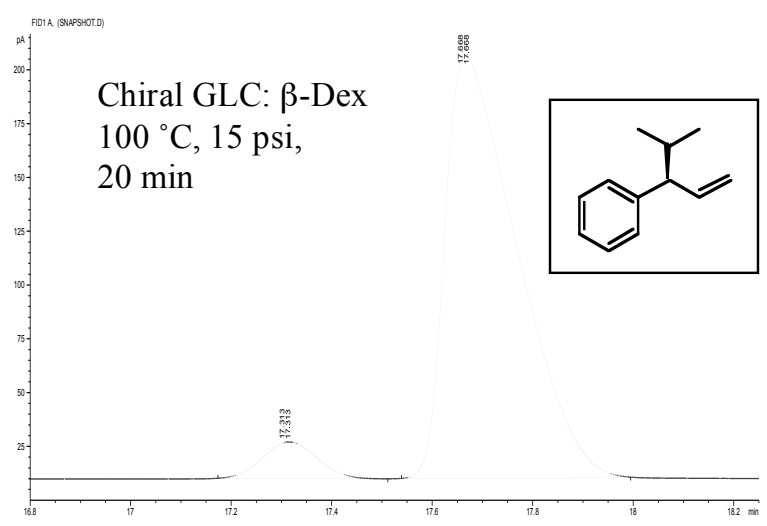

Authentic Racemic Sample

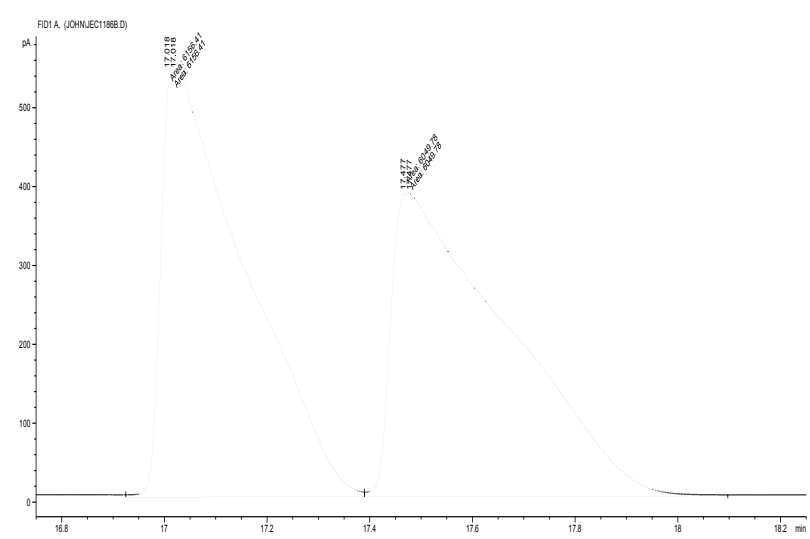


(S)-3-(o-Nitrophenyl)-1-butene (Table 2, entry 5). (Method A) IR (neat): 3087 (w), 2968 (m), 2936 (s), 2861 (m), 1621 (w), 1533 (s), 1457 (m), 1369 (s), 1016 (w), 922 (m), 853 (m), 790 (m), $758(\mathrm{~m}), 714(\mathrm{w}), 652(\mathrm{w}) .{ }^{1} \mathbf{H}$ NMR $\left(400 \mathrm{MHz}, \mathrm{CDCl}_{3}\right): \delta$ 7.24-7.75 (m, 4H, ArH); 5.97 (ddd, $J$ $=16.5,11.0,5.9 \mathrm{~Hz}, 1 \mathrm{H}, \mathrm{C}=\mathrm{CH}) ; 5.06-6.12(\mathrm{~m}, 2 \mathrm{H}, \mathrm{C}=\mathrm{CH}) ; 4.05(\mathrm{dq}, J=7.0,5.8 \mathrm{~Hz}, 1 \mathrm{H}$, $\operatorname{ArCH}) ; 1.40\left(\mathrm{~d}, J=7.0 \mathrm{~Hz}, 3 \mathrm{H}, \mathrm{CH}_{3}\right) .{ }^{13} \mathbf{C} \mathbf{N M R}\left(100 \mathrm{MHz}, \mathrm{CDCl}_{3}\right): \delta 141.2,139.7,132.8$, 129.3, 127.2, 124.3, 114.8, 37.3, 20.5. Anal. Calcd for $\mathrm{C}_{10} \mathrm{H}_{12} \mathrm{NO}_{2}$ : C, 67.78; H, 6.26; N, 7.90; Found: C, 67.47; H, 6.43; N, 8.84. $[\alpha]_{\mathrm{D}}^{25}\left(c=0.680, \mathrm{CHCl}_{3}\right):-1.38^{\circ}$.

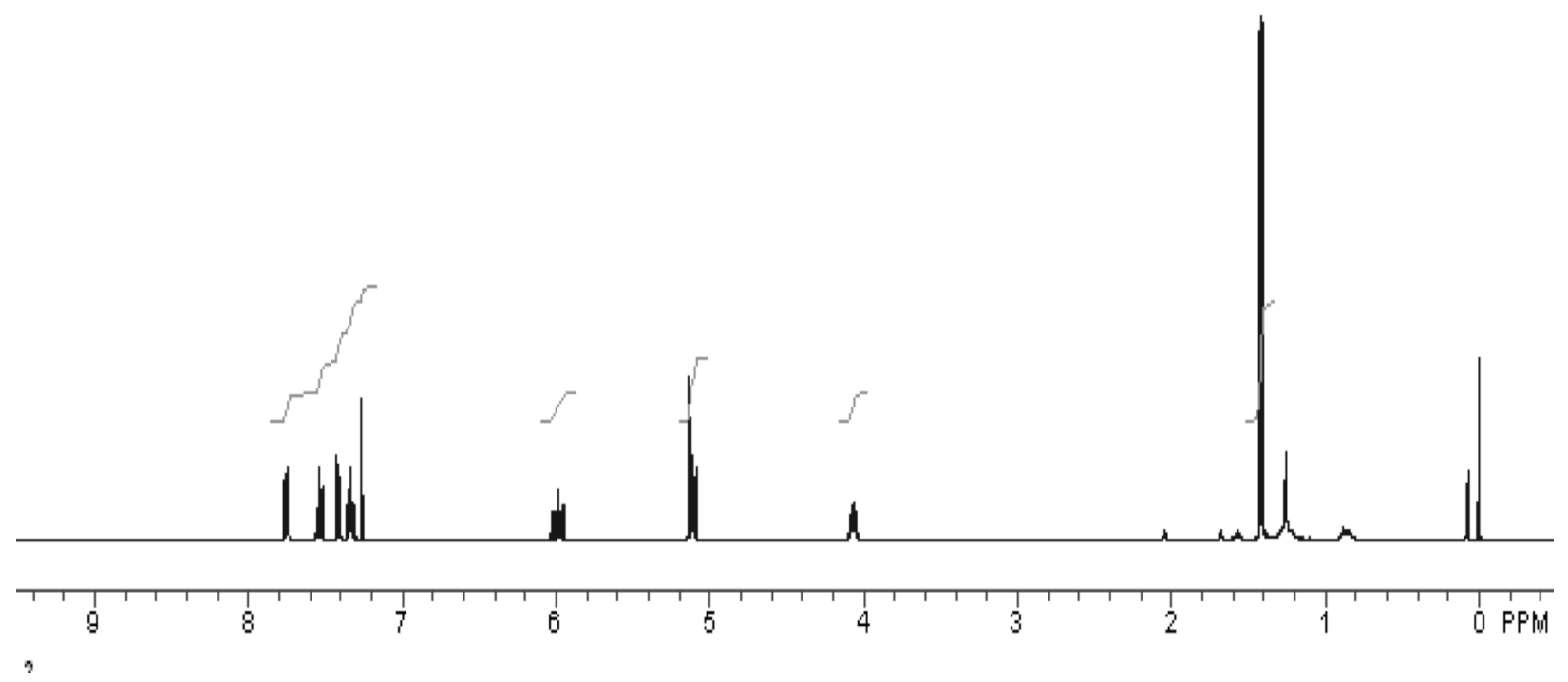

Enantioenriched Sample (91\% ee)

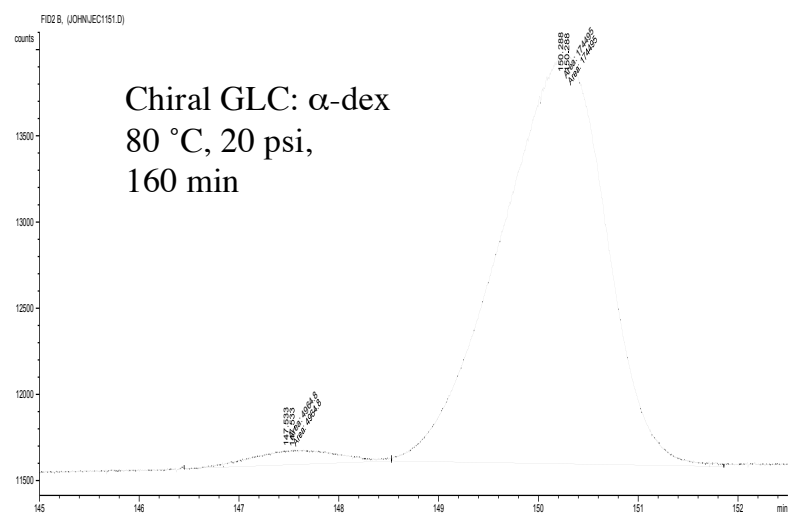

Authentic Racemic Sample

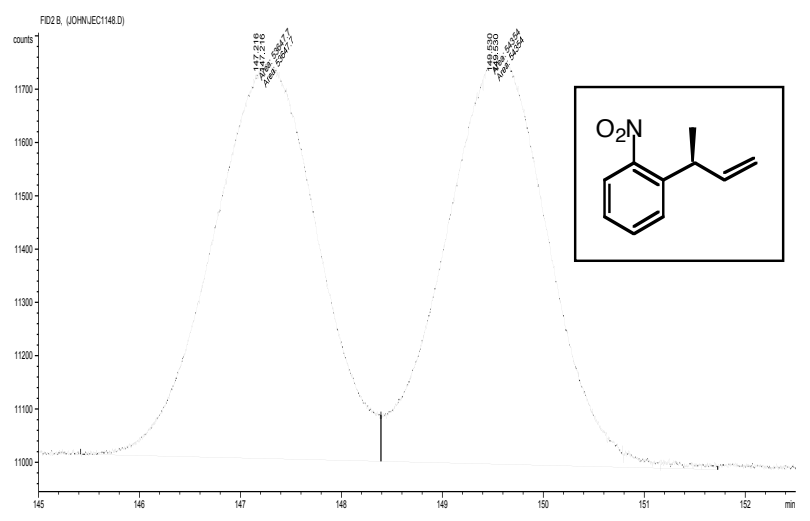


(S)-3-Cyclohexyl-1-heptene (Table 2, entry 11). (Method C) IR (neat): 3075 (w), 2943 (m), 2867 (m), 1646 (w), 1451 (m), 1010 (w), 916 (m). ${ }^{1} \mathbf{H}$ NMR (400 MHz, $\mathrm{CDCl}_{3}$ ): $\delta 5.54$ (ddd, $J=$ 17.0, 10.0, $0.7 \mathrm{~Hz}, 1 \mathrm{H}, \mathrm{C}=\mathrm{CH}), 4.95(\mathrm{dd}, J=10.0,2.2 \mathrm{~Hz}, 1 \mathrm{H}, \mathrm{C}=\mathrm{CH}), 4.87$ (ddd, $J=17.0,2.2$, $0.7 \mathrm{~Hz}, 1 \mathrm{H}, \mathrm{C}=\mathrm{CH}), 1.55-1.80\left(\mathrm{~m}, 6 \mathrm{H}, \mathrm{CH}_{2} \mathrm{CH}_{2}\right.$ and $\left.\mathrm{CyCH}\right), 0.8-1.45,\left(\mathrm{~m}, 15 \mathrm{H}, \mathrm{CH}_{2} \mathrm{CH}_{2}\right.$ and $\left.\mathrm{CH}_{3}\right) .{ }^{13} \mathbf{C} \mathbf{N M R}\left(100 \mathrm{MHz}, \mathrm{CDCl}_{3}\right): \delta 142.0,114.8,50.3,42.0,31.6,31.4,30.0,29.9,27.0,26.9$, 26.9, 23.0, 14.3. Anal. Calcd for $\mathrm{C}_{13} \mathrm{H}_{24}$ : C, 86.59; H, 13.41; Found: C, 86.30; H, 13.62. [ $\left.\alpha\right]_{\mathrm{D}}{ }^{25}(c$ $\left.=0.750, \mathrm{CHCl}_{3}\right):+12.0^{\circ}$.

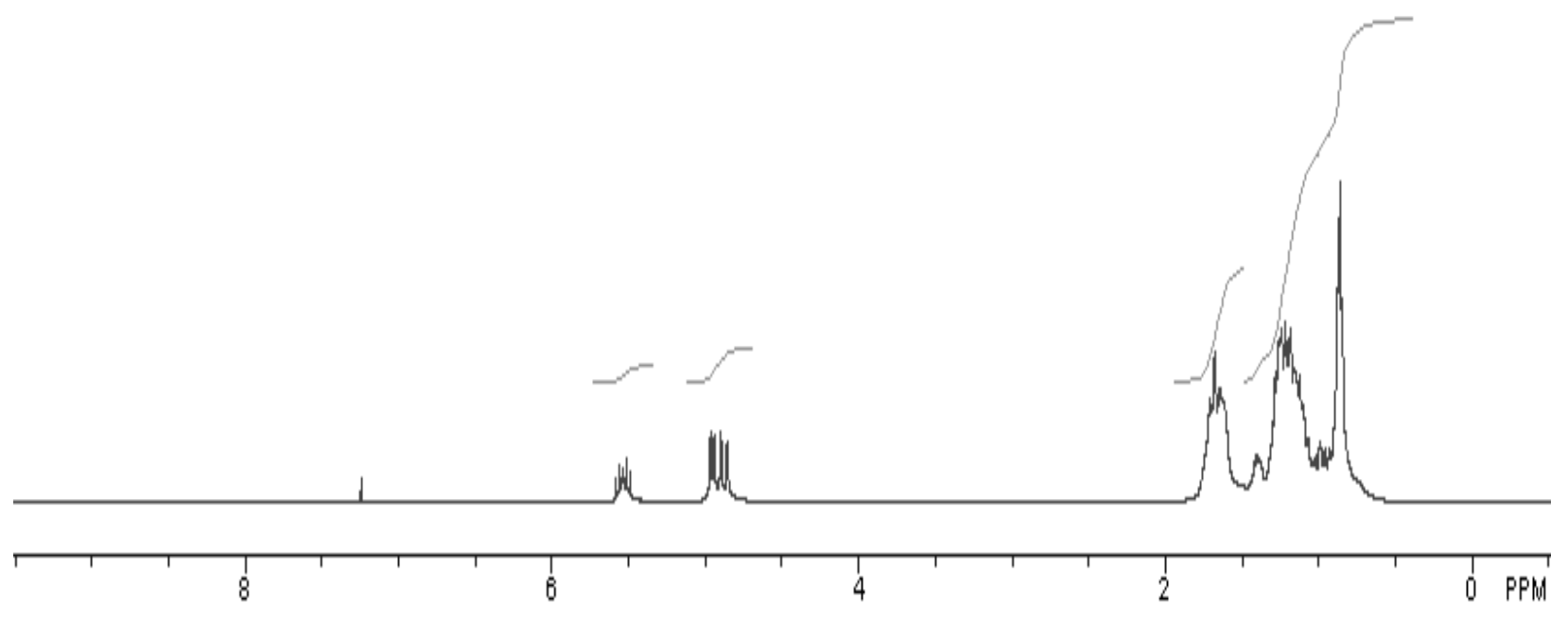
sm

Enantioenriched Sample $(96 \%$ ee)

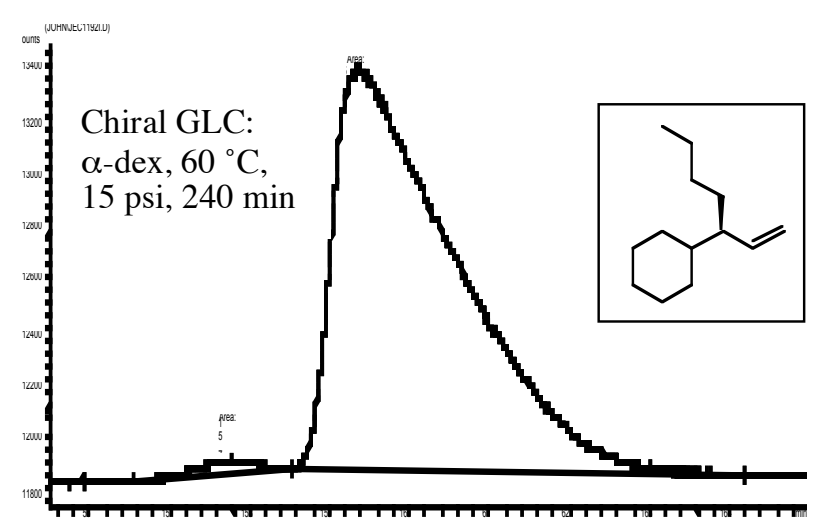

\section{Authentic Racemic Sample}

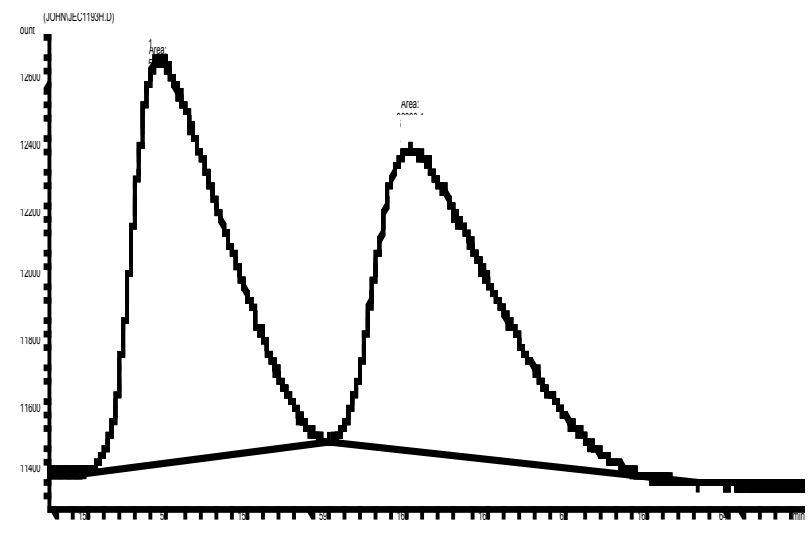


(S)-3-Cyclohexyl-4-methyl-1-pentene (Table 2, entry 12). (Method C) IR (neat): 2974 (s), 2923 (s), 2873 (s), 1646 (w), 1473 (m), 1456 (m), 1425 (w), 1392 (m), 1369 (m), 1014 (m), 920 (s), $733(\mathrm{w}), 683(\mathrm{w}) .{ }^{1} \mathbf{H}$ NMR $\left(400 \mathrm{MHz}_{\mathrm{CDCl}}\right): \delta 5.51(\mathrm{dt}, J=17.0,10.0 \mathrm{~Hz}, 1 \mathrm{H}, \mathrm{C}=\mathbf{C H})$, $5.01(\mathrm{dd}, J=10.2,2.5 \mathrm{~Hz}, 1 \mathrm{H}, \mathrm{C}=\mathrm{CH}), 4.86(\mathrm{ddd}, J=17.0,2.5,0.5 \mathrm{~Hz}, 1 \mathrm{H}, \mathrm{C}=\mathrm{CH}), 1.77(\mathrm{spt}, J$ $\left.=6.5 \mathrm{~Hz}, 1 \mathrm{H}, \mathrm{CH}\left(\mathrm{CH}_{3}\right)_{2}\right), 0.90-1.75\left(\mathrm{~m}, 12 \mathrm{H}, \mathrm{CyH}\right.$ and $\left.\mathrm{H}_{2} \mathrm{C}=\mathrm{CHCH}\right), 0.85(\mathrm{~d}, J=6.5 \mathrm{~Hz}, 3 \mathrm{H}$, $\left.\mathrm{CH}_{3}\right), 0.77\left(\mathrm{~d}, J=6.7 \mathrm{~Hz}, 3 \mathrm{H}, \mathrm{CH}_{3}\right) .{ }^{13} \mathbf{C} \mathbf{N M R}\left(100 \mathrm{MHz}, \mathrm{CDCl}_{3}\right): \delta 139.3,116.3,57.1,32.0$, 30.0, 27.4, 27.0, 26.9, 21.7, 18.9. Anal. Calcd for $\mathrm{C}_{12} \mathrm{H}_{22}$ : C, 86.67; H, 13.33; Found: C, 86.89; $\mathrm{H}, 13.01 .[\alpha]_{\mathbf{D}}{ }^{25}\left(c=0.713, \mathrm{CHCl}_{3}\right):+7.15^{\circ}$.

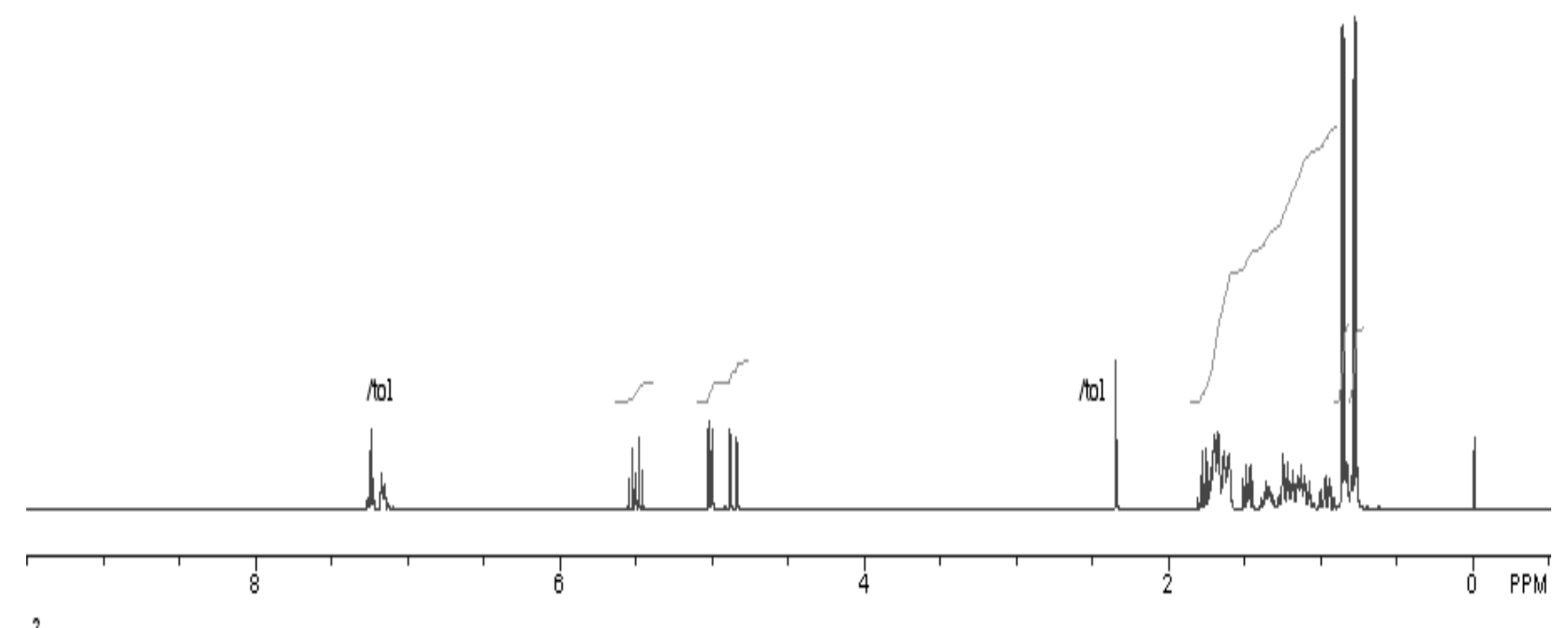

Enantioenriched Sample (97\% ee)

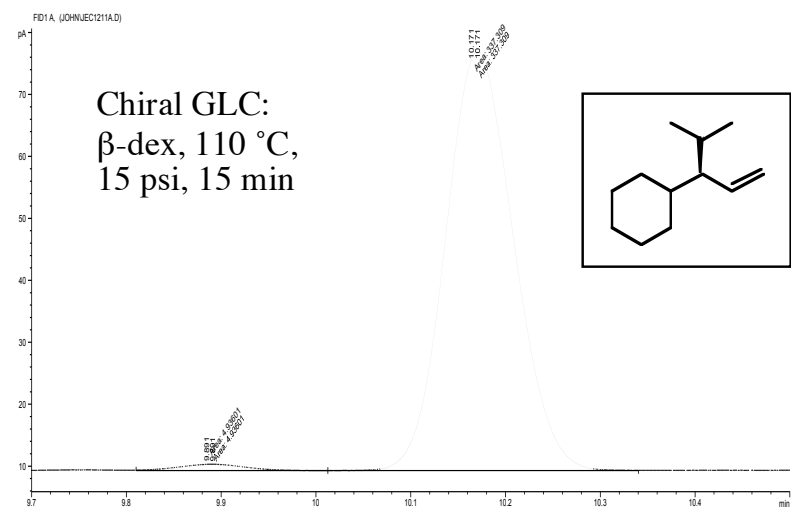

Authentic Racemic Sample

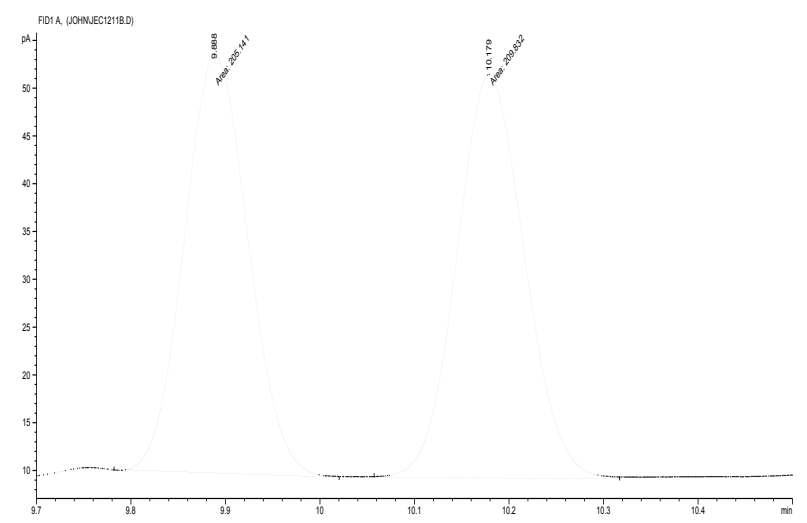


(S)-3-Isopropyl-3-phenyl-1-butene (Table 3, entry 2). (Method C) IR (neat): 3081 (w), 3062 (w), 2974 (m), 2936 (m), 2867 (m), 1639 (w), 1612 (w), 1501 (w), 1445 (w), 1400 (w), 1042 (w), 916 (m), 770 (m), 696 (s). ${ }^{1} \mathbf{H}$ NMR (400 MHz, $\mathrm{CDCl}_{3}$ ): $\delta$ 7.14-7.35 (m, 5H, ArH), 6.16 $(\mathrm{dd}, J=17.6,11.1 \mathrm{~Hz}, 1 \mathrm{H}, \mathrm{C}=\mathrm{CH}), 5.17(\mathrm{dd}, J=10.9,1.4 \mathrm{~Hz}, 1 \mathrm{H}, \mathrm{C}=\mathrm{CH}), 5.05$ (dd, $J=17.7$, $1.6 \mathrm{~Hz}, 1 \mathrm{H}, \mathrm{C}=\mathrm{CH}), 2.19\left(\mathrm{spt}, J=7.0 \mathrm{~Hz}, 1 \mathrm{H}, \mathrm{CH}\left(\mathrm{CH}_{3}\right)_{2}\right), 1.32\left(\mathrm{~s}, 3 \mathrm{H}, \mathrm{CH}_{3}\right), 0.84$ (d, J = $6.7 \mathrm{~Hz}$, $\left.3 \mathrm{H}, \mathrm{CH}_{3}\right), 0.76\left(\mathrm{~d}, J=6.8 \mathrm{~Hz}, 3 \mathrm{H}, \mathrm{CH}_{3}\right) .{ }^{13} \mathbf{C ~ N M R}\left(100 \mathrm{MHz}, \mathrm{CDCl}_{3}\right): \delta 148.4,144.9,128.2$, 126.8, 125.7, 113.3, 47.7, 36.3, 20.7, 18.4, 17.9. HRMS Calcd for $\mathrm{C}_{13} \mathrm{H}_{18}$ : 174.1409. Found: 174.1407. Anal. Calcd for $\mathrm{C}_{13} \mathrm{H}_{18}: \mathrm{C}, 88.59$; H, 10.41; Found: C, 88.94; H, 10.78. $[\alpha]_{\mathbf{D}}{ }^{25}(c=$ 1.80, $\mathrm{CHCl}_{3}$ ): $+41.8^{\circ}$.

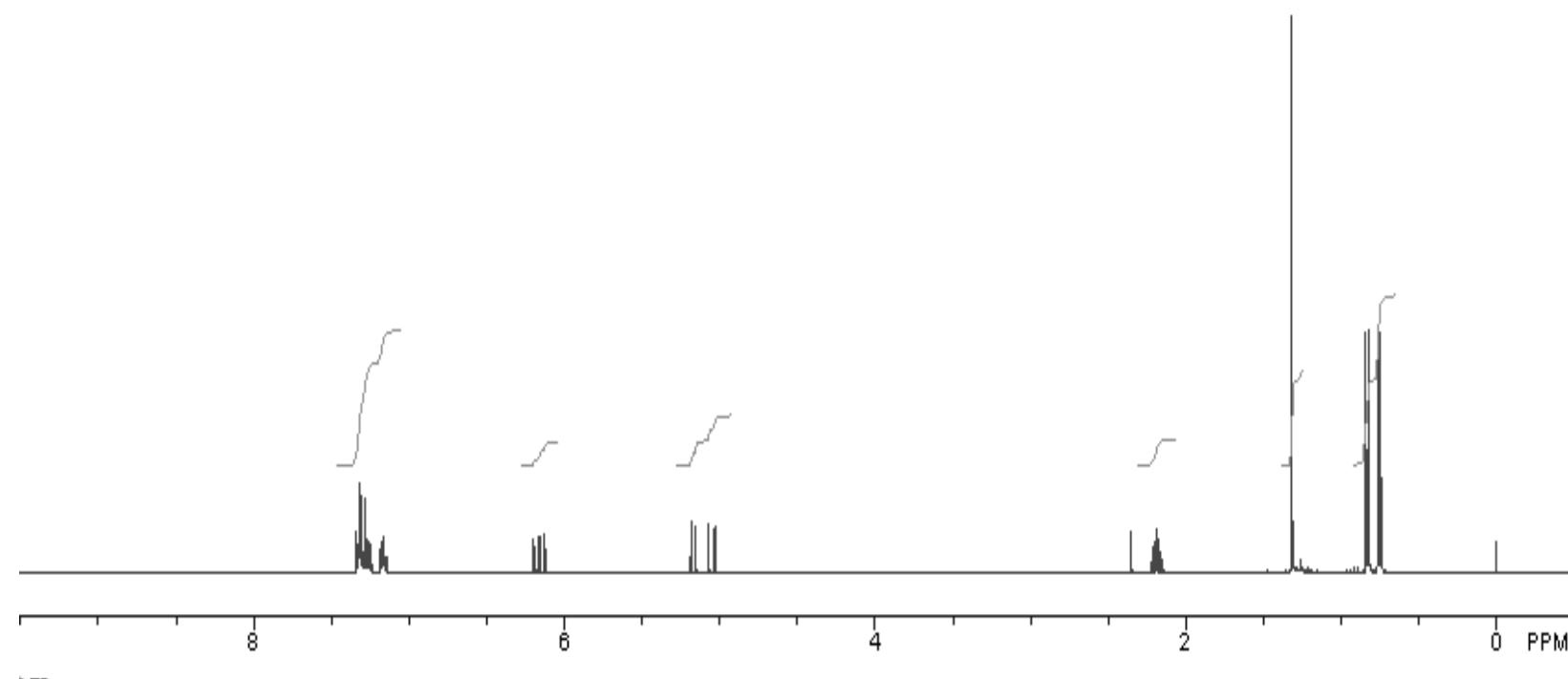

Enantioenriched Sample (98\% ee)

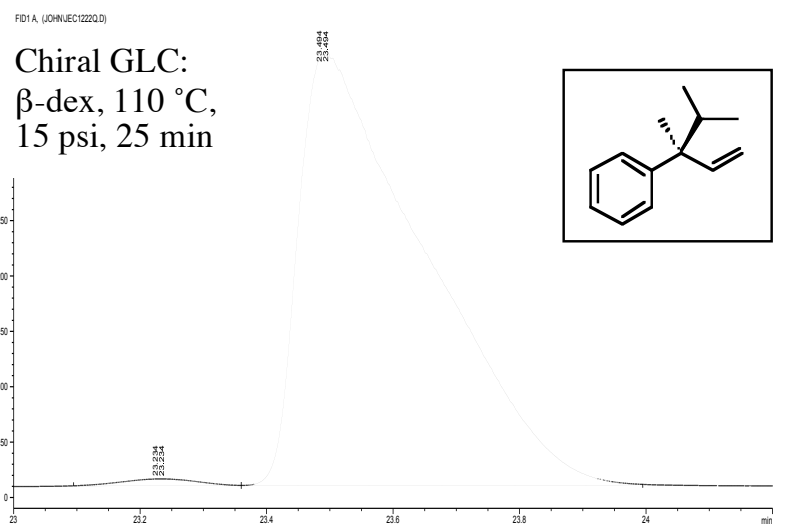

Authentic Racemic Sample

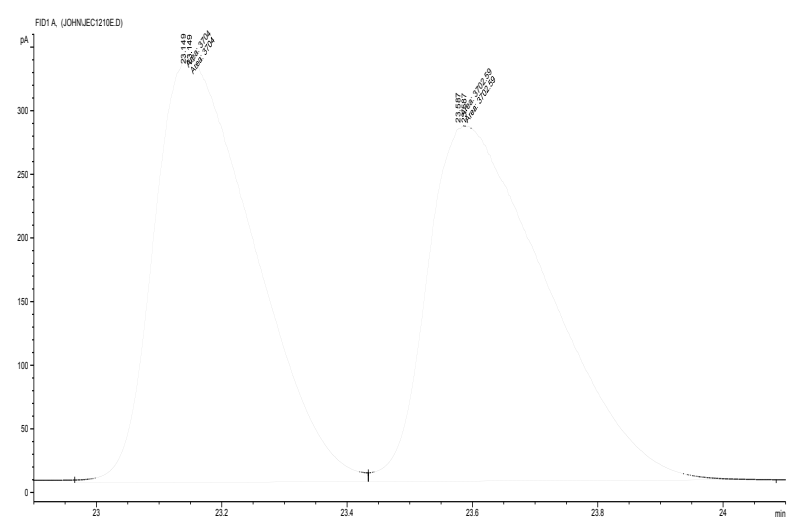


(R)-3-Phenyl-3-(p-nitrophenyl)-1-pentene (23). (Method A) IR (neat): 3087 (w), 2980 (m), 2923 (m), 2886 (w), 2848 (w), 1602 (m), 1520 (s), 1350 (s), 1111 (w), 1004 (w), 928 (w), 860 (s), 708 (s). ${ }^{1} \mathbf{H}$ NMR (400 MHz, $\mathrm{CDCl}_{3}$ ): $\delta 8.11$ (m, 2H, ArH), 7.19-7.36 (m, 5H, ArH), 7.14$7.10(\mathrm{~m}, 2 \mathrm{H}, \mathrm{ArH}), 6.42(\mathrm{ddd}, J=17.5,10.7,0.8 \mathrm{~Hz}, 1 \mathrm{H}, \mathrm{C}=\mathrm{CH}), 5.26(\mathrm{dt}, J=10.7,1.0 \mathrm{~Hz}, 1 \mathrm{H}$, $\mathrm{C}=\mathrm{CH}), 4.77(\mathrm{dt}, J=17.5,0.8 \mathrm{~Hz}, 1 \mathrm{H}, \mathrm{C}=\mathrm{CH}), 2.32\left(\mathrm{q}, J=7.0 \mathrm{~Hz}, 2 \mathrm{H}, \mathrm{CH}_{2} \mathrm{CH}_{3}\right), 0.77(\mathrm{t}, J=$ $\left.7.2 \mathrm{~Hz}, 3 \mathrm{H}, \mathrm{CH}_{3}\right) .{ }^{13} \mathbf{C} \mathbf{N M R}\left(100 \mathrm{MHz} \mathrm{CDCl}_{3}\right): \delta 158.2,155.0,145.5,143.2,129.7,128.6$, 128.5, 126.7, 123.3, 115.7, 54.6, 31.6, 9.5. Anal. Calcd for $\mathrm{C}_{17} \mathrm{H}_{17} \mathrm{NO}_{2}: \mathrm{C}, 76.38 ; \mathrm{H}, 6.41 ; \mathrm{N}$, 5.24; Found: C, 76.54; H, 6.70; N, 5.13. $[\alpha]_{\mathrm{D}}{ }^{25}\left(c=1.89, \mathrm{CHCl}_{3}\right):+11.4^{\circ}$.

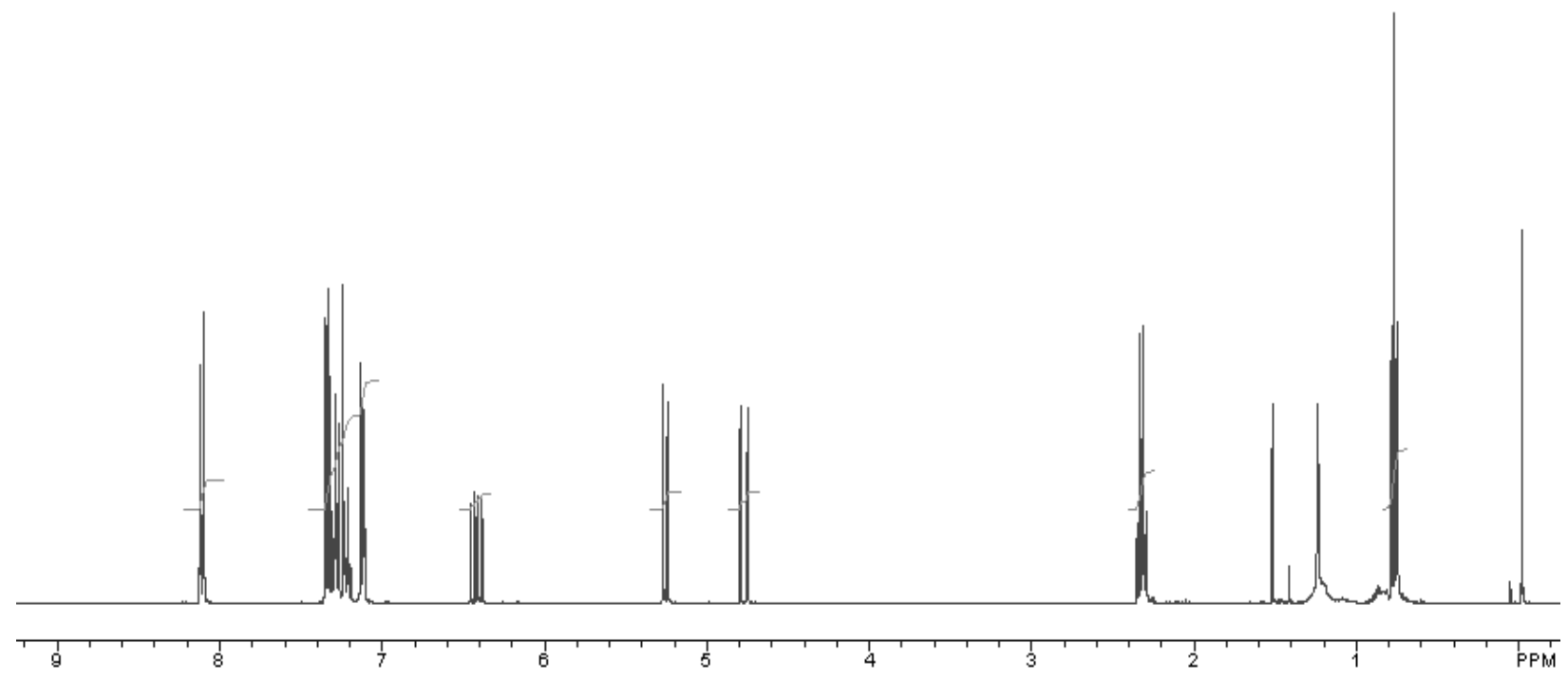

Enantioenriched Sample $(85 \%$ ee $)$

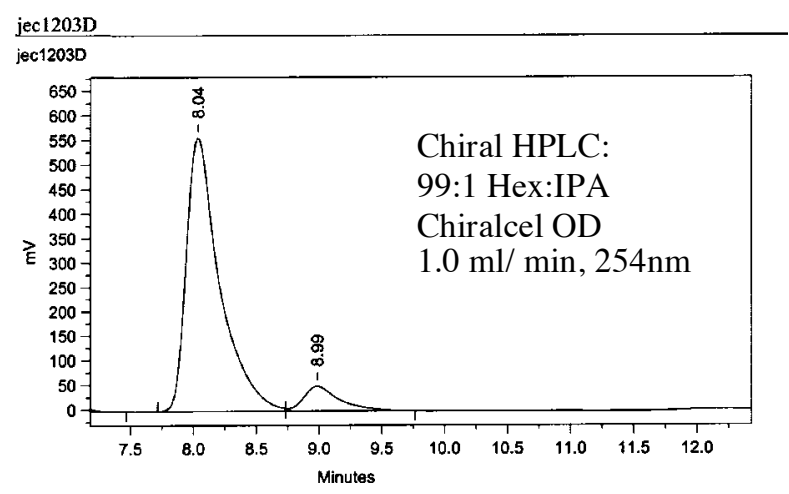

Authentic Racemic Sample

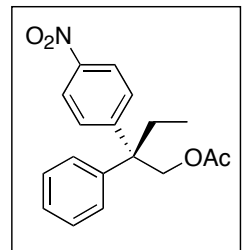


(S)-3-(o-Methoxyphenyl)-3-methyl-1-pentene (Scheme 4). (Method B) IR (neat): 3087 (w), 2980 (s), 2936 (s), 2880 (m), 2836 (w), 1646 (w), 1595 (m), 1495 (s), 1463 (s), 1438 (s), 1237 (s), 1180 (m), 1098 (m), 1046 (s), 922 (m), 771 (s). ${ }^{1} \mathbf{H}$ NMR (400 MHz, $\mathrm{CDCl}_{3}$ ): $\delta 7.21$ (m, 2H, $\operatorname{ArH}), 6.88(\mathrm{~m}, 2 \mathrm{H}, \operatorname{ArH}), 6.24(\mathrm{dd}, J=17.0,11.0 \mathrm{~Hz}, 1 \mathrm{H}, \mathrm{C}=\mathrm{CH}), 4.99(\mathrm{dd}, J=11.0,2.0 \mathrm{~Hz}$, $1 \mathrm{H}, \mathrm{C}=\mathrm{CH}), 4.93(\mathrm{dd}, J=17.0,2.0 \mathrm{~Hz}, 1 \mathrm{H}, \mathrm{C}=\mathrm{CH}), 3.79\left(\mathrm{~s}, 3 \mathrm{H}, \mathrm{OCH}_{3}\right), 1.94$ (ddq, $J=117.1$, 13.5, 7.5 Hz, 2H, $\left.\mathrm{CH}_{2} \mathrm{CH}_{3}\right), 1.41\left(\mathrm{~s}, 3 \mathrm{H}, \mathrm{CH}_{3}\right), 0.69\left(\mathrm{t}, J=7.5 \mathrm{~Hz}, 3 \mathrm{H}, \mathrm{CH}_{3}\right) .{ }^{13} \mathbf{C} \mathbf{N M R}(100$ $\left.\mathrm{MHz}, \mathrm{CDCl}_{3}\right): \delta 158.4,147.4,135.4,128.5,127.5,120.5,112.0,110.7,55.3,44.6,31.6,23.9$, 9.5. Anal. Calcd for $\mathrm{C}_{13} \mathrm{H}_{18} \mathrm{O}$ : C, 82.06; H, 9.53; Found: C, 81.89; H, 9.82. $[\alpha]_{\mathrm{D}}{ }^{25}(c=0.527$, $\left.\mathrm{CHCl}_{3}\right):+9.11^{\circ}$.

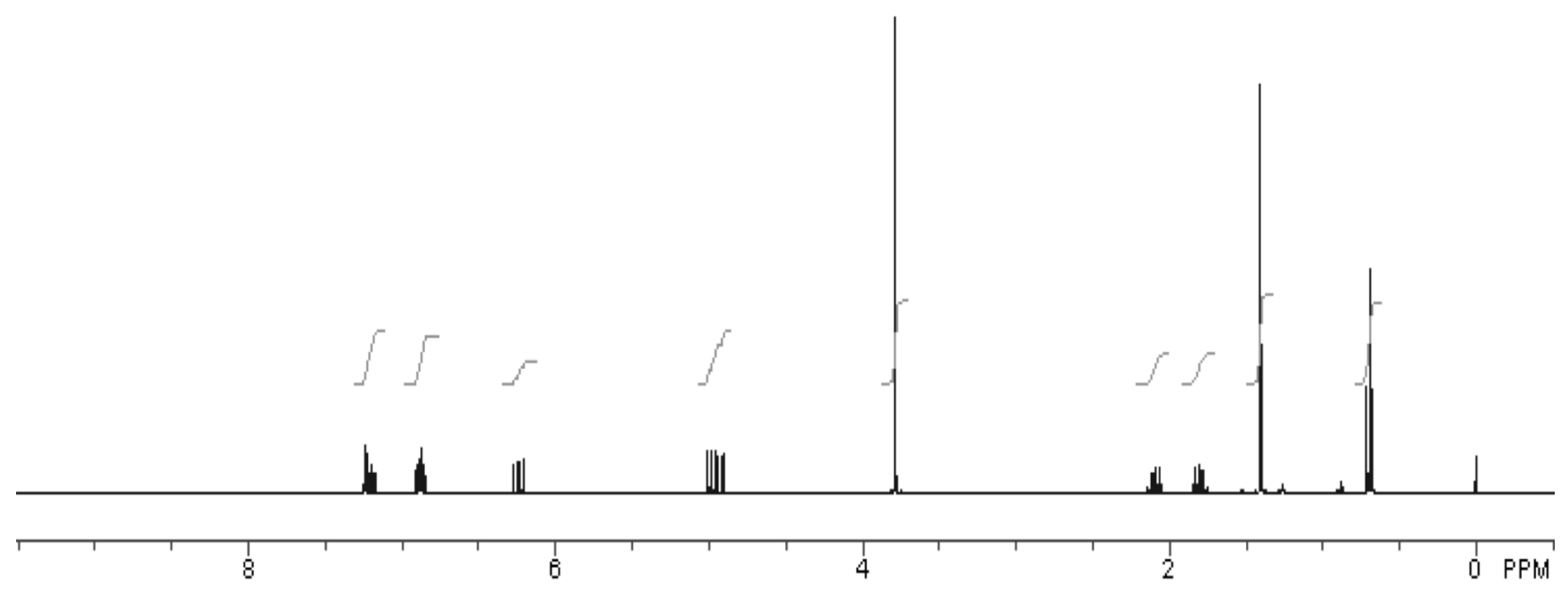

Enantioenriched Product $(98 \%$ ee)

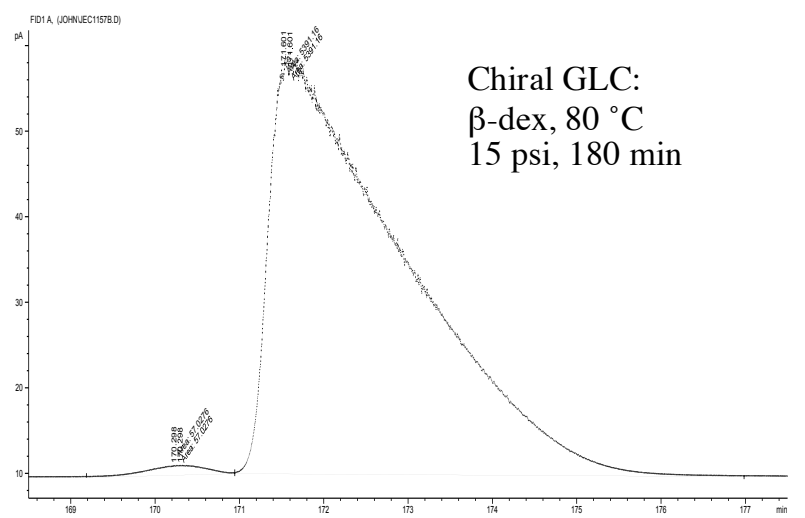

\section{Authentic Racemic Sample}

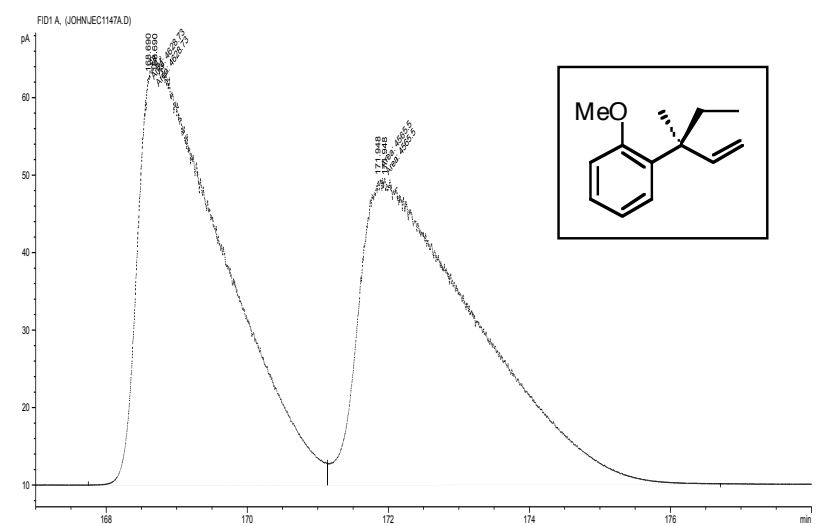


(S)-3-Phenyl-1-butene (Table 2, entry 1).

(See ref. 7) HRMS Calcd for $\mathrm{C}_{10} \mathrm{H}_{12}: 132.0939$. Found: 132.0934.

Enantioenriched Product $(90 \%$ ee)

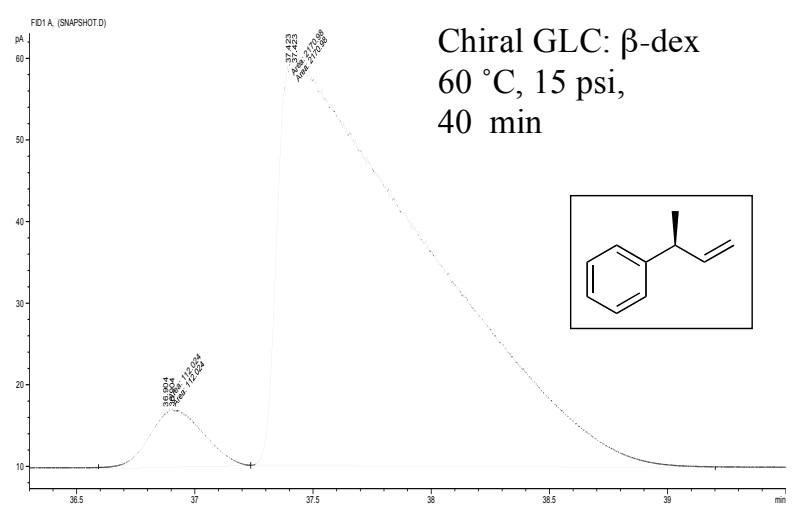

(S)-3-Phenyl-1-pentene (Table 2, entry 2).

(See ref. 6,7)

Enantioenriched Product $(90 \%$ ee)

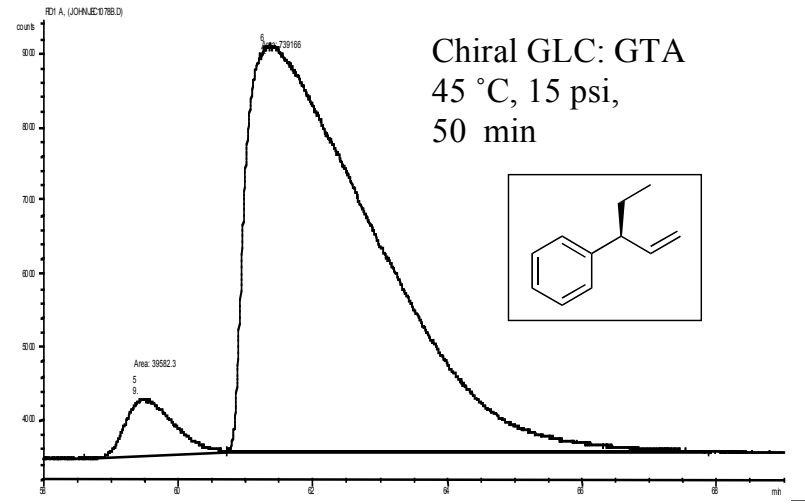

Authentic Racemic Sample

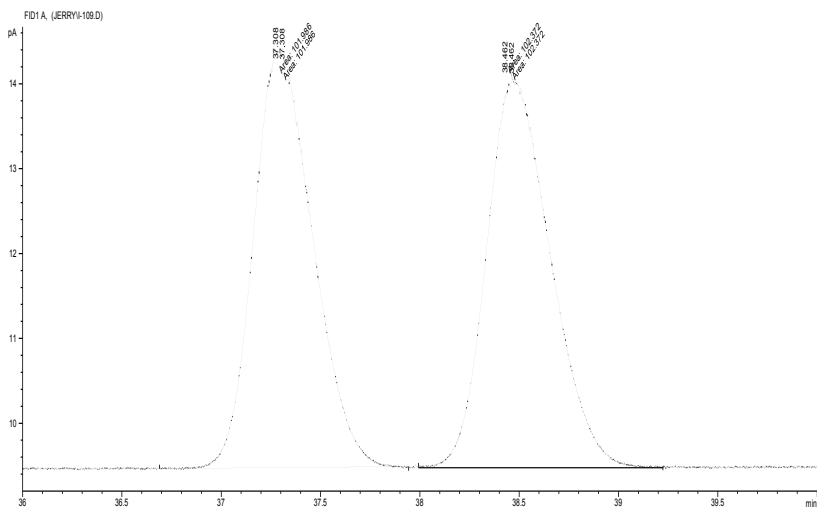

(S)-3-o-Nitrophenyl-1-pentene (Table 2, entry 6).

(See ref. 6,7) HRMS Calcd for $\mathrm{C}_{11} \mathrm{H}_{13} \mathrm{NO}_{2}$ : 177.0790. Found: 177.0787. Anal. Calcd For $\mathrm{C}_{11} \mathrm{H}_{13} \mathrm{NO}_{2}$ : C, 69.09; H, 6.85, N, 7.32, Found: C, 69.38; H, 7.17, N, 7.09.

Enantioenriched Product (90\% ee)

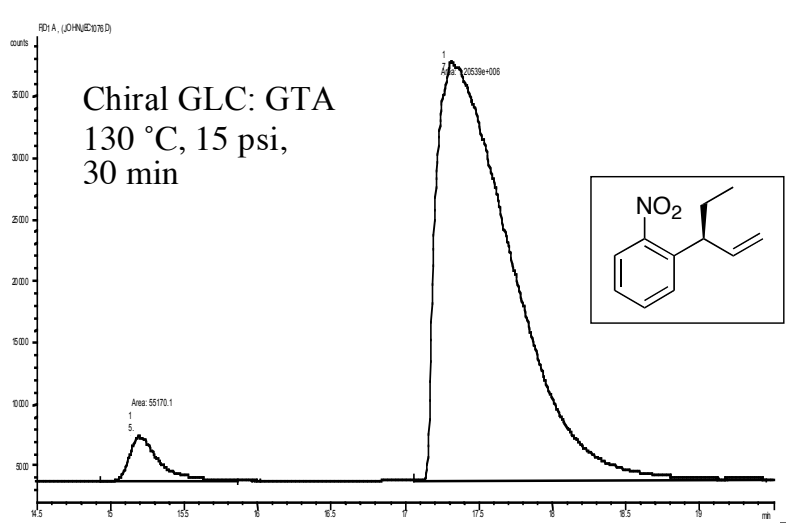

\section{Authentic Racemic Sample}

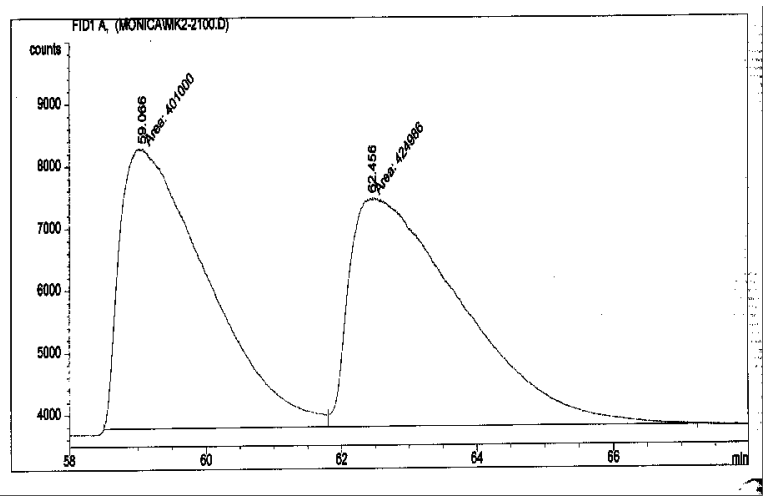

Authentic Racemic Sample

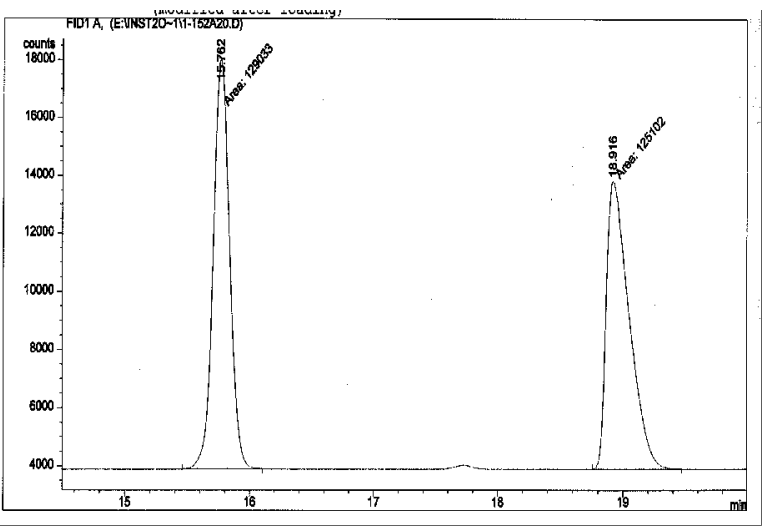


(S)-3-Methyl-1-decene (Table 2, entry 7).

(See ref. 6) HRMS Calcd for $\mathrm{C}_{11} \mathrm{H}_{22}: 154.1722$. Found: 154.1726. Anal. Calcd For $\mathrm{C}_{11} \mathrm{H}_{22}: \mathrm{C}$, 85.63; H, 14.37, Found: C, 85.64; H, 14.35.

Enantioenriched Product $(88 \%$ ee)

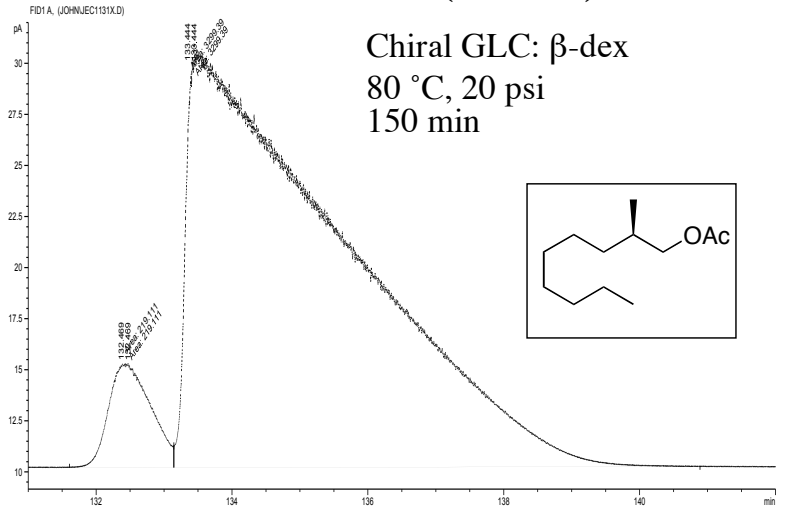

Authentic Racemic Sample

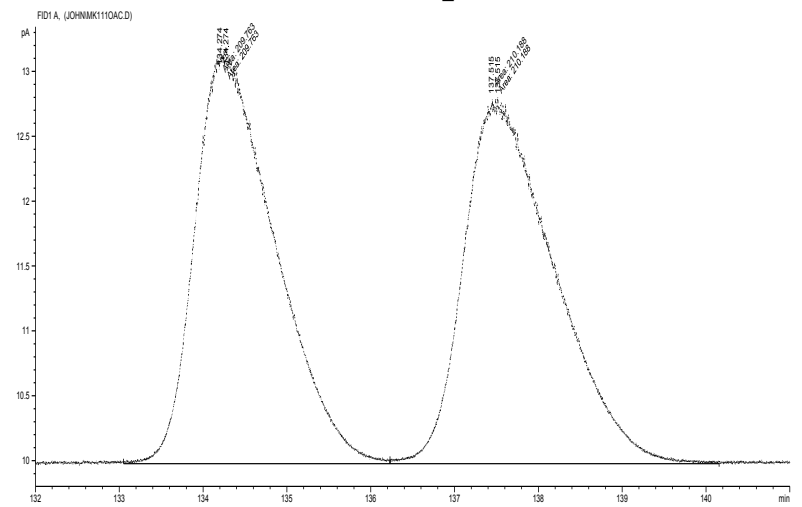

(S)-3-Ethyl-1-decene (Table 2, entry 8).

(See ref. 6) HRMS Calcd for $\mathrm{C}_{12} \mathrm{H}_{24}$ : 168.1878. Found: 168.1875.

Enantioenriched Product (88\% ee)

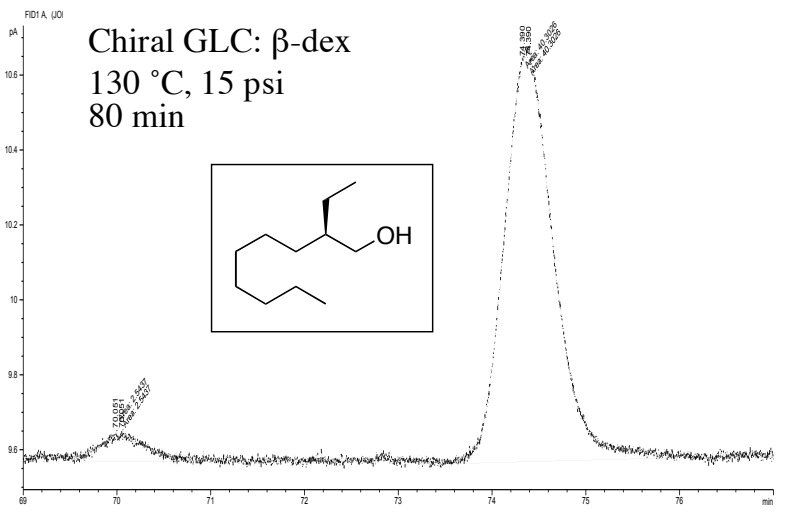

Authentic Racemic Sample

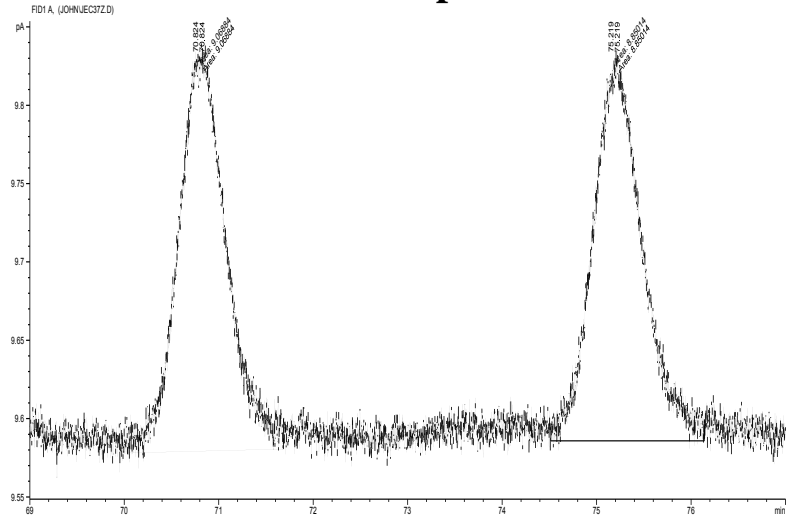

(S)-3-Cyclohexyl-1-butene (Table 2, entry 9).

(See ref. 6) HRMS Calcd for $\mathrm{C}_{10} \mathrm{H}_{18}$ : 138.1409. Found: 138.1407.

Enantioenriched Product (95\% ee)

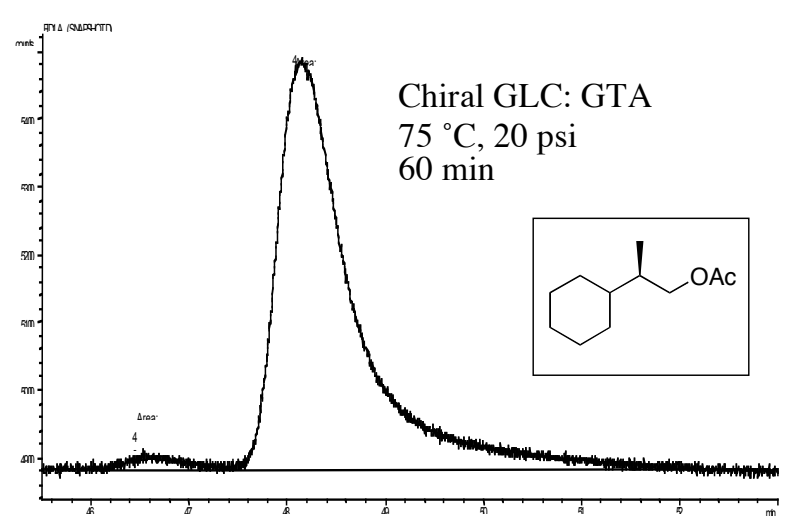

Authentic Racemic Sample

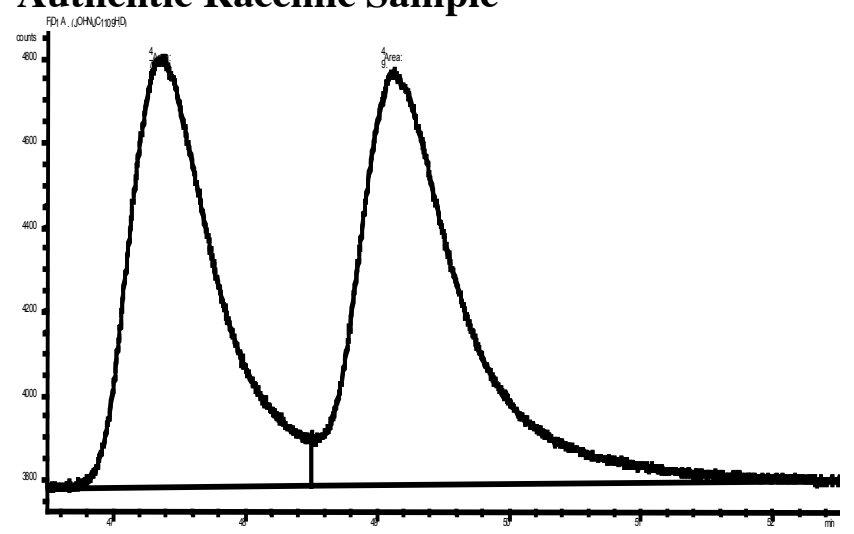


(S)-3-Cyclohexyl-1-pentene (Table 2, entry 10).

(See ref. 7) HRMS Calcd for $\mathrm{C}_{11} \mathrm{H}_{20}: 152.1565$. Found: 152.1559.

Enantioenriched Product (95\% ee)

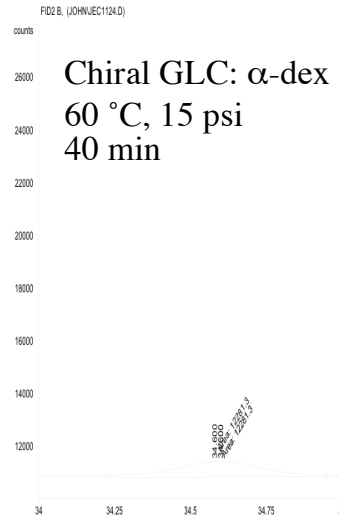

Authentic Racemic Sample

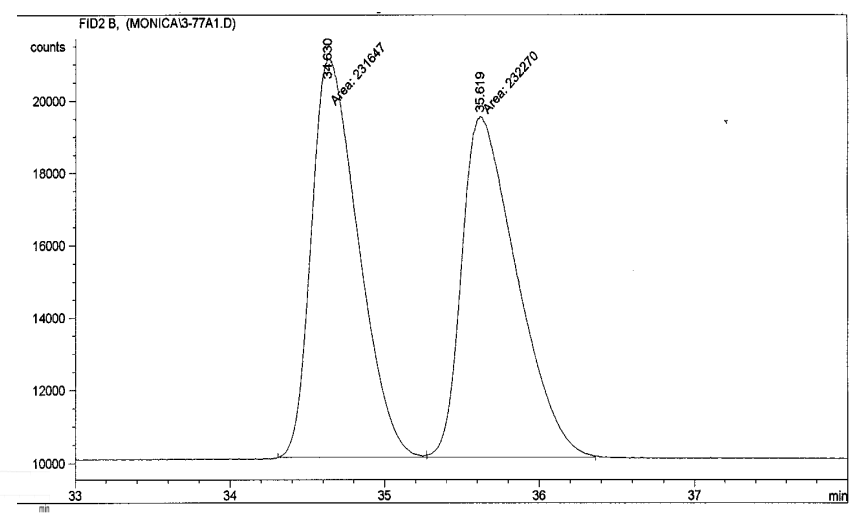

(R)-3-Phenyl-1-pentene. (21a).

(See ref. 6,7)

Enantioenriched Product (88\% ee)

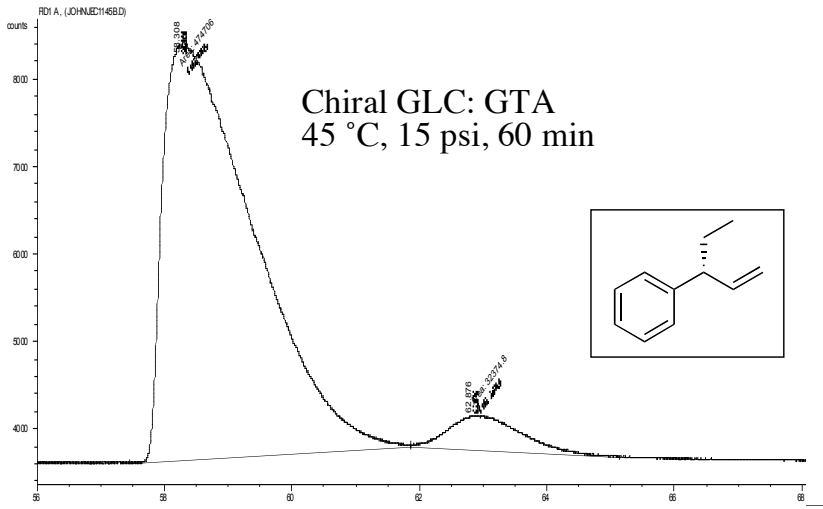

Authentic Racemic Sample

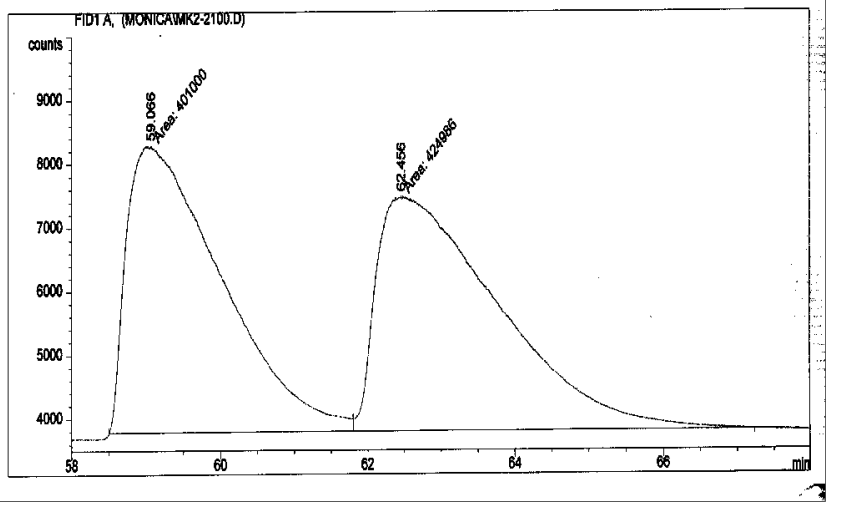

(R)-3-Phenyl-3-methyl-1-pentene (21b).

(See ref. 6,7)

Enantioenriched Product $(75 \%$ ee)

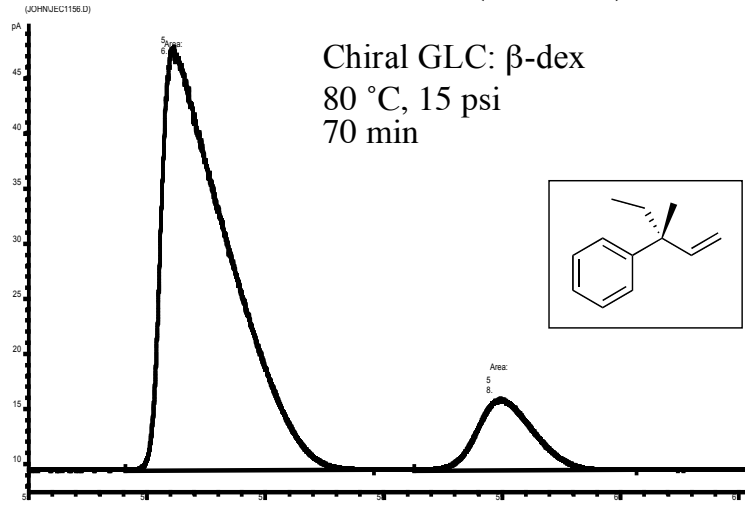

Authentic Racemic Sample

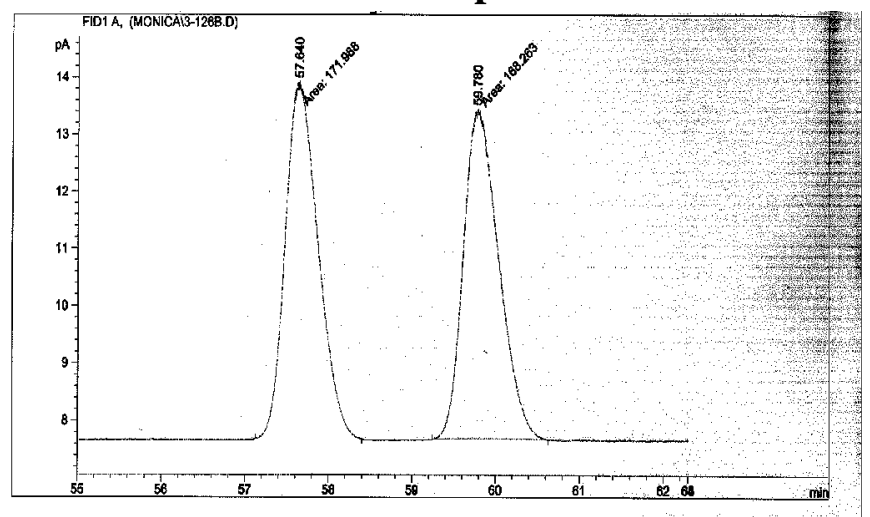


(S)-3-Phenyl-3-methyl-1-pentene (Table 3, entry 1).

(See ref. 6,7)

Enantioenriched Product (97\% ee)

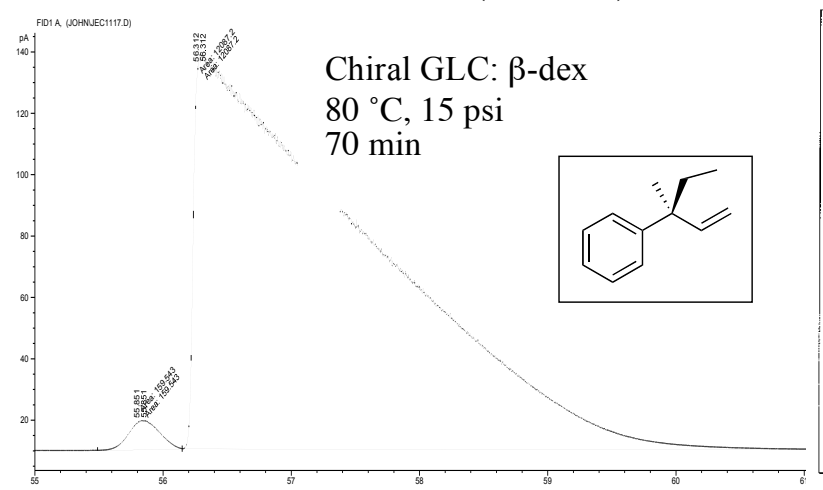

Authentic Racemic Sample

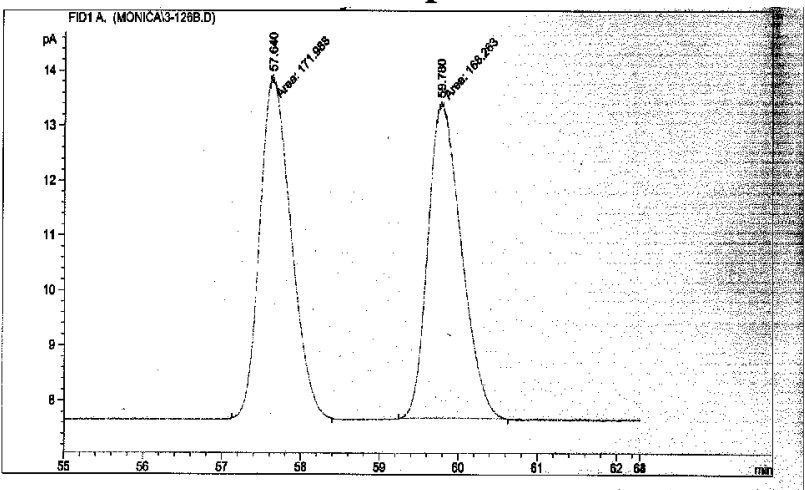

(S)-3-Methyl-3-cyclohexyl-1-pentene (Table 3, entry 3).

(See ref. 7) HRMS Calcd for $\mathrm{C}_{12} \mathrm{H}_{22}: 166.1722$. Found: 166.1715 .

Enantioenriched Product (97\% ee)

Authentic Racemic Sample
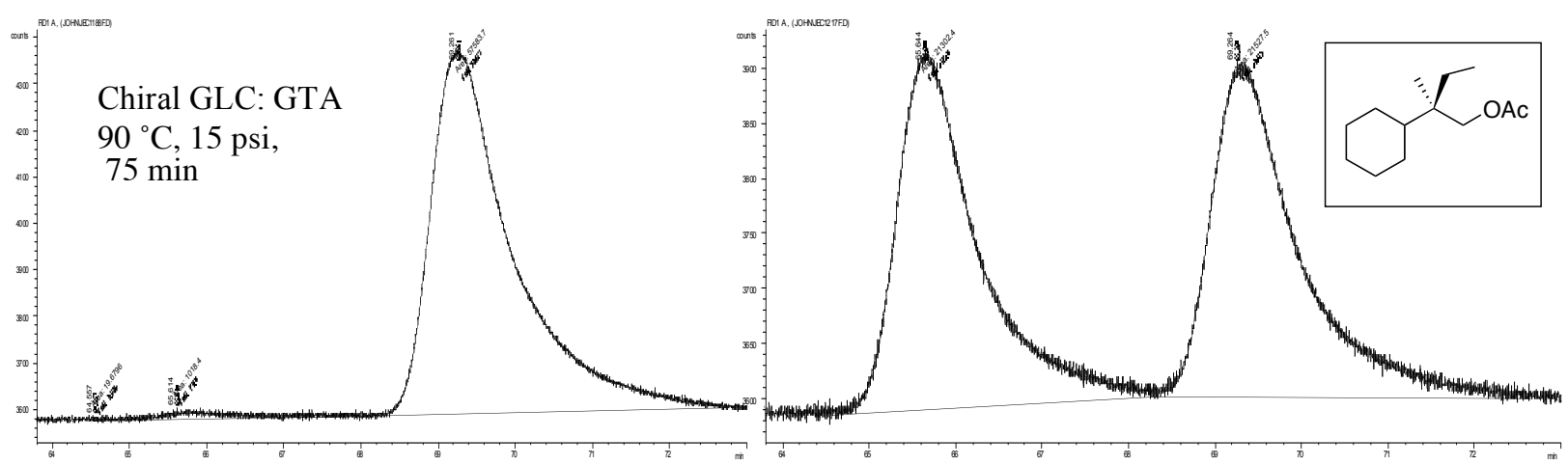

(S)-3-Methyl-3-ethyl-7-methyl-octa-1,6-diene (Table 3, entry 4).

(See ref. 7)

Enantioenriched Product (94\% ee)

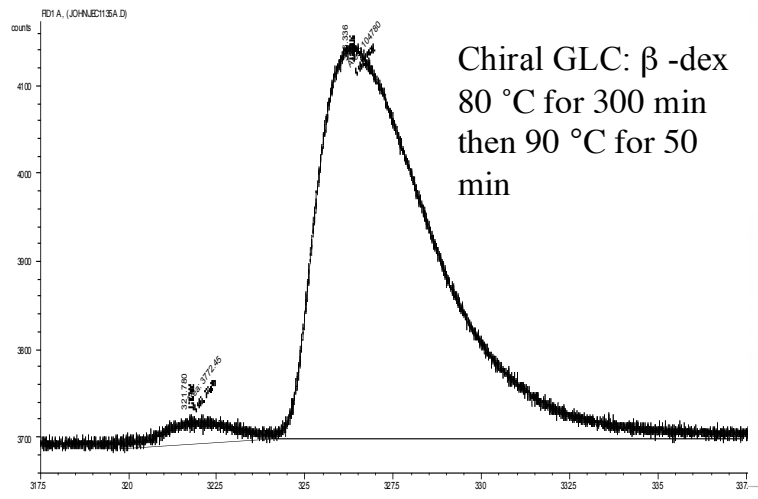

Authentic Racemic Sample

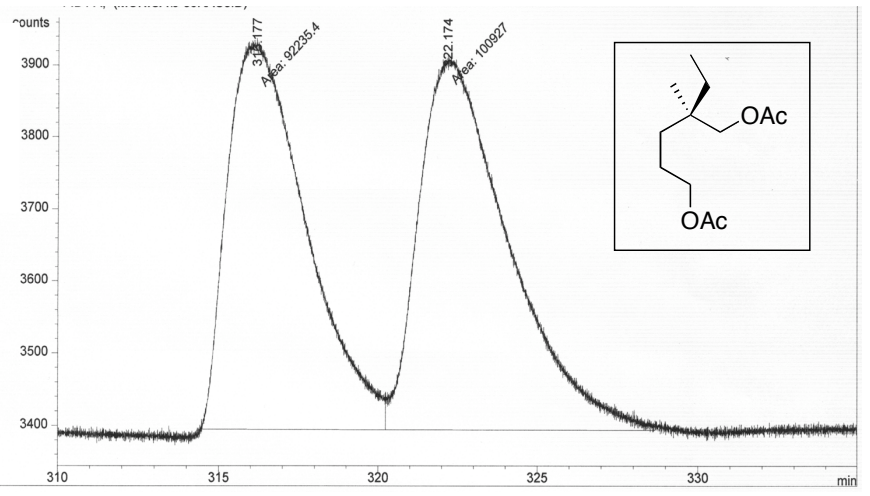

